Portland State University

PDXScholar

Civil and Environmental Engineering Master's

Project Reports

Winter 2018

\title{
Mechanisms Controlling Copper Transport in Natural Soils
}

Julie A. Luisi

Portland State University

Follow this and additional works at: https://pdxscholar.library.pdx.edu/cengin_gradprojects

Part of the Environmental Engineering Commons, and the Soil Science Commons Let us know how access to this document benefits you.

\section{Recommended Citation}

Luisi, Julie A., "Mechanisms Controlling Copper Transport in Natural Soils" (2018). Civil and Environmental Engineering Master's Project Reports. 40.

https://doi.org/10.15760/CCEMP.39

This Project is brought to you for free and open access. It has been accepted for inclusion in Civil and Environmental Engineering Master's Project Reports by an authorized administrator of PDXScholar. Please contact us if we can make this document more accessible: pdxscholar@pdx.edu. 


\section{Mechanisms Controlling Copper Transport in Natural Soils}

BY

Julie A. Luisi

A research project report submitted in partial fulfillment of the requirement for the degree of 


\section{MASTER OF SCIENCE \\ IN \\ CIVIL AND ENVIRONMENTAL ENGINEERING}

Project Advisor:

Gwynn R. Johnson, PhD.

Portland State University

(C)2017 


\section{ACKNOWLEDGMENTS}

Obtaining my Masters of Science would not have been possible without the mentorship of Dr. Gwynn R. Johnson. I thank her for recognizing my ability, allowing me to explore various topics and her willingness to support each one, and for pushing me to what she knew I was capable of achieving.

Additionally, to my lab mates in Dr. Johnson's lab who brought their tough questions to me and with those, the challenge of finding the answers. Thanks to Emily in particular, for knowing the value of talking to oneself aloud as a method of problem solving and for being there when talking to myself was not enough.

I would also like to thank the Banker and Bentley Labs for their support and flexibility while I attended school and for trusting that I would maintain the high work standards I set for myself while taking on this new responsibility.

Finally, I would like to thank my family, especially Gwen and Ceto, for their patience and managing on their own during my long days and many late nights over the years of full time work and graduate school. 


\begin{abstract}
Biosolids are used as amendments to agricultural soils and can be a source of trace metals. It is unknown if these land-applied trace metals travel through the soil column to the water table. This study aims to determine the transport behavior of copper in natural soils, including 'aged' soils, commercial agricultural soils that have had multiple years of biosolids applications. Using acid digests and Darcy column apparatus it was determined that factors such as $\mathrm{pH}$, soil composition, especially organic matter content, and the presence of other trace metals influence copper's complex transport behavior in these soils. Natural soil appears to filter the metal precipitates that form at environmental $\mathrm{pH}$. Under certain conditions, these trace metal precipitates can become mobile. There is also evidence of competition for soil binding sites between iron and copper.
\end{abstract}




\section{TABLE OF CONTENTS}

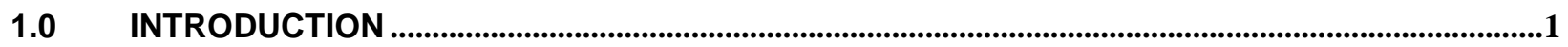

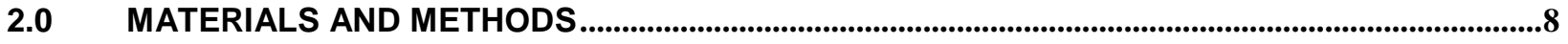

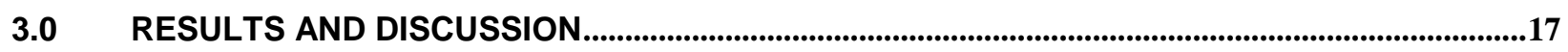

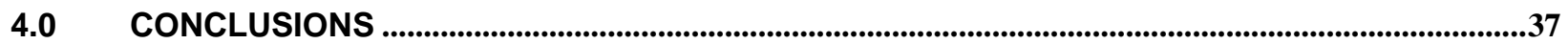

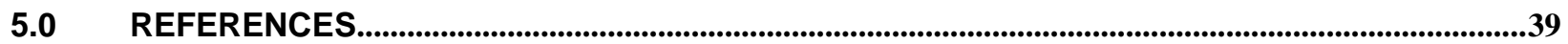




\section{LIST OF TABLES}

Table 1: Reagents for 1000X southern California Rainwater stock. Final volume $500 \mathrm{ml}$ in aerated nanopure water. Sourced from Fisher Scientific and ACS grade except where noted. 11

Table 2: Concentrations and molar ratios of irrigation water and mixed trace metal solution.

Table 3: Mass of total copper per gram of soil determine by acid digest arranged by soil type and treatment. 


\section{LIST OF FIGURES}

Figure 1: Tools used for packing columns. From top to bottom: tamping rod, scoop, and stylus. 13

Figure 2: Effects of leachate from fresh soil on copper concentration readings. RW2 (-\#) refers to RW at pH2.0 while the -\# refers to the triplicate. FS refers to samples with fresh soil added.

Figure 3: Chemical analysis of ion in copper only solution using Visual Minteq software.......................19

Figure 4: Chemical analysis of ion in mixed trace metals solution using Visual Minteq software ..............20

Figure 5: Media composition determined by particle size distribution and organic matter by ignition........21

Figure 6: Copper concentration determined by acid digest on various soils. Sand had no detectible

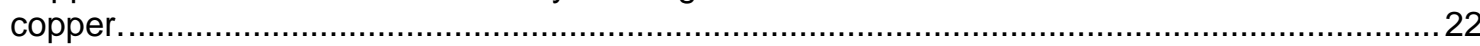

Figure 7: Copper concentration determined by acid digest of fresh soil exposed to copper solution at $\mathrm{pH}$ 6.0 for 40 pore volumes and diagram of the position in the column for each batch sample and direction of flow.

Figure 8: Non-reactive tracer (PFBA) in sand and fresh soil columns.

Figure 9: First 10 pore volumes of PFBA and mixed trace metals solution on sand and mixed trace metals solution on fresh soil (measuring copper concentration).

Figure 10: Full curve of mixed trace metals solution on fresh soil showing copper and iron concentrations as well as $\mathrm{pH}$.

Figure 11: Copper solution at pH 2.2 on fresh soil showing enhanced arrival ......................................2

Figure 12: Comparison of copper concentration of copper solution $(\mathrm{pH} 4.9)$ on fresh and aged soils with sample $\mathrm{pH}$ indicated.

Figure 13: Normalized curves from Figure 12 to compare curve shape of copper arrival of copper solution $(\mathrm{pH} 4.9)$ on fresh and aged soils with sample $\mathrm{pH}$ indicated.

Figure 14: Comparison of copper arrival curves on fresh soil for each injection solution. ........................31

Figure 15: Normalized comparison copper curves (from Figure 14) on fresh soil for each injection solution.

Figure 16: Copper concentrations at different levels in the fresh soil column under various conditions. $\mathrm{Cf}=$

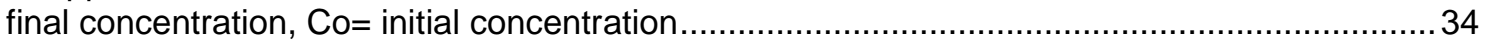

Figure 17: Mixed trace metals solution on fresh soil with several stop flow episodes............................ 36 


\subsection{INTRODUCTION}

A recent study published in The Lancet, one of the oldest peer-reviewed medical publications, evaluated the effects of pollution on human health worldwide (Landrigan et al. 2017). According to this study, 'Pollution is the largest environmental cause of disease and premature death in the world today'. In 2015, pollution and the resulting diseases amounted to $16 \%$ of the worldwide mortality rate, an estimated 9 million deaths. Repeatedly, chemicals that are released to the environment prior to determining their effects on human health and the environment are culpable for episodes of ecosystem decline, disease and death (Landrigan et al. 2017). As a result, The Lancet Commission issued six recommendations. One of these recommendations is research of pollutants and the environmental risk associated with their presence in the natural environment. To ensure effective policies aimed to protect human health and the environment, a clear understanding of mechanisms controlling the transport and fate of pollutants is needed.

Land application of sewage sludge is commonly employed as a disposal means for sludge generated in the treatment of wastewaters. In 1993, the EPA published and began to implement 'The Standards for the Use or Disposal of Sewage Sludge (Title 40 of the Code of Federal Regulations [CFR], Part 503)' (Walker et al. 1994). Known as 'the Part 503 rule' and 'Part 503', this regulation aims to protect human health and the environment from adverse effects of targeted pollutants that may be present in sewage sludge (biosolids). Part 503 is the governing document for the standards of land-applied biosolids, though states may have requirements that are more rigorous.

Biosoilds are the dewatered sludge from wastewater treatment plants prepared to meet landapplication standards. The wastewater sludge is first treated by various means to remove harmful pathogens. The methods of treatment can include aerobic or anaerobic digestion with or without the application of heat. Once pathogens have been reduced or eliminated, up to $95 \%$ of the water is removed. These biosolids are high in organic material and contain inorganic matter such as phosphorus, potassium, nitrogen, calcium, iron, copper, zinc, and magnesium (EPA, 1994). Pollutants commonly present in biosolids include trace metals, pharmaceuticals, nanoparticles and other emerging pollutants (Wu et al 2010; Xing et al 2016; Machno and Leonard, 2017).

Additionally, trace metals are commonly concentrated in biosolids especially in those sludges from wastewater treatment plants receiving stormwater or industrial discharge (Coruh et al. 2006; McKenzie et al. 2009; Clary et al. 2011; Al-Saydeh et al. 2017; Hussain et al. 2017). For example, 
sludges from these treatment plants potentially contain relatively high concentrations of trace metals such as iron, zinc, lead and copper. Trace metals often bind to organic matter making these metals likely to accumulate in biosolids.

There are three grades of biosolids: Class A, Class B, and Exceptional Quality (EQ) (Walker et al. 1994). Class A biosolids have levels of pathogens (e.g., fecal coliform and Salmonella bacteria, enteric viruses, and viable helminth ova) that are below detection limits. Class $B$ has pathogens detected but at a level that do not pose a risk to public health and the environment. EQ Biosolids meet Class A pathogen requirements as well as low-level pollutant concentrations. For example, the ceiling concentration of copper in Class A and Class B is $4300 \mathrm{mg}$ copper $/ \mathrm{kg}$ biosolids (dry weight). To be considered EQ, that ceiling concentration for copper is $1500 \mathrm{mg} / \mathrm{kg}$. The grade of the biosolids is important in determining where and how they may be employed. For example, biosolids of varying grades are typically disposed by incineration, may be used in manufacturing such as cement, can be applied as a cover over landfills and commonly applied on agricultural land as previously mentioned.

The Clean Water Act requires that the scientific basis of the Part 503 rule be reassessed at least every two years (33 USC Section 1345(d)(2)(C)). As part of this requirement, the EPA requested an independent review by the National Research Council (NRC) of the chemical and pathogen regulations with a focus solely on human health. The results of the findings from the NRC, published in 2002, are entitled Biosolids Applied to Land: Advancing Standards and Practices (National Academies Press). According to these findings, sewage sludge usage as soil conditioners, fertilizers and for land reclamation increased significantly after 1992 when the disposal of wastewater residuals into the ocean was banned. Consequently, the land-application of sewage sludge decreased the volume of waste materials that needed to be incinerated, landfilled, or disposed of by other means (e.g., composted).

The review committee also found that the EPA had not addressed specific recommendations the NRC made in its 1996 review, published as Use of Reclaimed Water and Sludge in Food Crop Production (National Academies Press). In the 1996 review, the NRC summarized major concerns regarding the reliability of the data used to generate the EPA's risk evaluation in the National Sewage Sludge Survey (NSSS) published in 1988. In this survey, samples were collected from Publicly Owned Treatment Works (POTWs) in 40 cities throughout the US. These concerns included major data gaps in the biosolids data collected as well as regional variations such as 
climate, geology, use practices, and biosolids content not considered in the original risk assessment. In 1996, the NRC recommended that the EPA conduct a new survey of pollutants in sewage sludge to generate reliable national data (complete biosolids data at each POTW to include relevant regional data). Additionally, the NRC acknowledged in their review that more substances (i.e., pollutants) have since been identified as "toxic" while the technology for detecting and analyzing pollutants has improved since the original EPA sewage sludge survey. In addition to collecting more recent and reliable data, the NRC recommended a new/additional risk assessment based on complex mixtures of chemicals as well as chemical-pathogen mixtures (National Research Council, 2002).

In 2001, the EPA conducted a national survey specially to analyze dioxins and dioxin-like compounds in sewage sludge. The Agency determined the 'exposure to dioxins in land-applied biosolids is below levels of concern' (Office of Water, 2009) and no adjustments were made to Part 503. The EPA produced a new Targeted National Sewage Sludge Survey (TNSSS) in 2009. This 2009 survey was broad in its analytes, including reexamining the ten metals under current regulation. The samples collected for this survey were frozen and archived. Most of those archived samples were retested for an additional Sewage Sludge Survey in 2015 (some of the original samples from 2009 had insufficient material for additional testing in 2015 (Office of Water, 2015)). The 2015 testing was for total carbon, hydrogen, nitrogen, oxygen, sulfur, total organic carbon, total solids, volatile solids, fixed solids and silicon as silica. It did not include any additional information on trace metals or other potential pollutants of concern. Finally, in 2007, the Office of the Science Advisor and Risk Assessment Forum published Framework for Metals Risk Assessment (Office of the Science Advisor, 2007) as a guide for the EPA and other agencies in evaluating risks associated with trace metals, though no agency is obligated to use the guide. None of these new surveys nor the metals risk assessment publication have had any impact on the EPA's risk assessment for land-applied biosolids. The results of the original 1993 risk assessment as Part 503 remains unchanged.

The risk assessment of trace metals in Part 503 was based on a chemical-by-chemical analysis without consideration of chemical mixtures. The assessment calculated the amount of pollutant that could be land-applied for each trace metal, individually, without adverse effects to human health, animals, plants and soil microbes. Many variables were considered, including volatilization, leaching and erosion. While the EPA recognizes that trace metals can be mobile at low $\mathrm{pH}$, the Agency decided against requiring $\mathrm{pH}$ controls; citing current agronomic practices maintain soil $\mathrm{pH}$ 
above 6.0 (Walker \& Stein, 1995). Therefore, the assessment assumes the soil receiving the biosolids applications is near neutral $\mathrm{pH}$. At $\mathrm{pH}$ range of $6-8$, copper present in soils is primarily complexed with organic matter (Langmuir et al. 2004). Some of the organic matter that copper will bind to in this $\mathrm{pH}$ range could be soluble (i.e. dissolved $\mathrm{OM}$ ). Any copper that remains in solution as well as bound to dissolved OM has the potential to be mobile.

The risk assessment model in Part 503 fails to account for facilitated transport of contaminants by soluble organic material (National Research Council, 2002). For example, aqueous copper ion concentrations have been shown to decrease with the increase of either $\mathrm{pH}$ or dissolved organic carbon (Langmuir et al. 2004). Soluble copper may precipitate or form insoluble organocomplexes at higher $\mathrm{pH}$ or higher levels of dissolved organic carbon. Other trace metals can sorb to organic material as well, thereby affecting the overall trace metal accumulation in soils and possible competition for available binding sites in the organic material fraction of these soils (Benedetti et al. 1995; Nierop et al. 2002; Tipping et al. 2002; Tipping, 2005). Additionally, the EPA decided not to include iron as a pollutant in Part 503 because reports of toxicity were only observed at atypically high concentrations (Walker \& Stein, 1995). Iron is capable of sorbing to organic material. This means iron can be present in unregulated quantities in soils following the long-term land application of biosolids and those iron concentrations can compete for sites on organic material that might otherwise stabilize regulated trace metals. To represent accurately the transport and fate of trace metals, a risk assessment model needs to account for facilitated transport and the binding capacity of organic material in a mixture of trace metals with differing affinities to that organic material. Multiple trace metals are known to exist in biosolids and without characterization under complex albeit natural environmental condition there exists a risk of longterm and widespread pollution issues.

Pollution assessment and control, important components in the protection of human health and the environment is costly. Yet, pollution cleanup and pollution-related diseases have a significant cost to productivity and gross domestic product as noted by The Lancet Commission (Landrigan et al. 2017). Pollution control and more importantly pollution prevention are beneficial to both human health and the economy. Recent examples are evident, such as the lead in the drinking water in Flint, Michigan in 2016. The cost to add a chemical to the Flint water supply to keep the pipes from corroding further (one of the main reasons for the lead in the Flint drinking water) would have cost approximately $\$ 100$ per day (Popular Science, 2016). While this is not an insignificant cost, the state of Michigan has already spent $\$ 58$ million on water provisions and medical care in relation to 
this crisis. The cost to human health of those affected will be measured throughout their lifetimes, estimated to be around $\$ 400$ million (Muenning, 2016; Sanburn, 2016). Understanding the transport and fate of trace metals in the complex mixtures that are biosolids will help determine if widespread land-application of biosolids is setting up a costly cleanup in the future and if more prevention should be done now.

In California, where the samples for this study were collected, agricultural land-application is the most common use of biosolids (Moller, 2007). There are several benefits of land-applying biosolids in large agricultural fields. The high organic matter helps retain moisture, improves soil texture and enhances root formation (EPA, 1994). The inorganic matter, such as nitrogen and phosphorous, are nutrients needed for plant growth. Statewide in California, biosolids production and percent applied to agriculture land has increased from 1.395 million wet tons and $28 \%$, respectively, in 2010 to 3 million wet tons and 62\% in 2015 (Works \& Facilities, 2015; CASA, 2017). The biosolids applied to the study site came from the City of Los Angeles ('City'). According to City, the Hyperion wastewater treatment plant currently produces Class $A E Q$ biosolids by anaerobic digestion with applied heat $\left(53.3^{\circ} \mathrm{C}\right.$ for 12 days) (City of Los Angeles et al. 2014), meeting the EPA requirements for Class A biosolids (Walker et al. 1994). In 2014, all ten metals with limits established by Part 503 were under the required limits to qualify for EQ grade biosolids (Dafeta, 2015).

While Part 503 sets trace metal limits and requires that biosolids samples be tested at least once a year to as often as once a month, these requirements are the responsibility of the producers of the biosolids, typically, the municipal wastewater treatment plants and are performed prior to use of the biosolids for land-application (Walker et al. 1994). There are no provisions for on-site testing or monitoring of the accumulation and possible transport of trace metals in long-term continual landapplication of biosolids in Part 503. This study aims to characterize the transport behavior of copper in natural porous media under various environmental conditions. Copper was chosen for this study for its ease of analysis, levels present at the study site in both the soil and irrigation water and its being one of the ten trace metals regulated in Part 503 as a potential human health risk. Low levels of copper (e.g. $0.0057 \mathrm{mg}$ copper $/ \mathrm{kg}$ body weight) by oral exposure in humans (such as in drinking water) can have gastrointestinal effects (nausea, vomiting, and diarrhea) while high intakes of copper can cause liver and kidney damage and even death (ATSDR, 2004; Dorsey et al 2004). Of greater concern is copper's impact on surface water quality and specifically on fish populations. One example is that low-level dissolved copper concentrations $\left(5-20 \mathrm{ug} \mathrm{Cu}{ }^{2+} / \mathrm{L}\right)$ have 
been shown to reduce the response to predators in juvenile Coho salmon leaving them more vulnerable to predation (Mclntyre et al. 2012). This has the potential to decimate Coho salmon populations.

Several studies of successive annual applications of biosolids on agricultural soils indicate that the highest concentrations of trace metals associated with biosolids applications reside in the upper surface of the soil column (Chang et al. 1984; Dowdy et al. 1991; Schroder et al. 2008).

Additionally, Sepulvado et al. found that the accumulated concentrations of pollutants in those soils is directly proportional to the long-term annual, cumulative loading rate of biosolids (Sepulvado et al. 2011). The objective of this study is to investigate the impact of long-term, successive land application of biosolids on the overall transport behavior of trace metals through soil. This study includes natural porous media collected from (1) the surface soil layer $(0-30 \mathrm{~cm})$ at an agricultural field site in California, where land application of biosolids (with reported concentrations of Part 503 trace metals) have been employed for over 20 years as part of farming operations at the site. This agricultural soil represents an "aged" natural media, having had multiple, repeated applications of biosolids. Additionally, this study includes (2) a "fresh" natural porous media represented by a surface soil collected from a small-scale vegetable garden in Oregon having eight years of annual home compost plus composted chicken manure applications as well as one commercial mushroom compost application (during year two). In comparison, the transport of trace metals through (3) a "zero- contact" media was also investigated using a well-characterized natural porous media collected from a sand quarry in Canada.

It may be of interest to note, the site selected for collection of agricultural soil with long-term, repeated biosolids applications has historically been irrigated with the effluent from a local sewage treatment plant. This irrigation water has been analyzed and found to contain trace metals, including copper and comparatively high levels of iron in solution. As mentioned previously, iron is not regulated by Part 503 while iron can compete with other metals, including copper, for sorption sites in natural soils. With continued, long-term applications of trace metals from two sources, i.e., irrigation and biosolids, plus no established or required on-site monitoring by EPA's Part 503, it may be of interest to qualify the overall transport and fate behavior of copper through these aged surface soils. For example, if copper is able to become mobile under variable environmental conditions it could reach the water table and become a more widespread environmental risk. 
This study includes experiments wherein various natural soils (described above) were exposed to aqueous-phase copper and to copper in solution with other aqueous-phase trace metals at multiple $\mathrm{pH}$ ranges. These experiments were designed to look at steady state flow to evaluate transport of copper under long-term exposure. The experiments revealed complex interactions between the trace metals and the natural soils. Some conditions allowed high concentrations of copper to become mobile. 


\subsection{MATERIALS AND METHODS}

\subsection{Porous Media}

Three types of natural porous media were used for this study: a silica-sand, natural surface "fresh" soil and an "aged" agricultural soil. The sand is a highly characterized, well-known uniform silica sand called 40/50 Accusand (Unimin Corporation, New Canaan, CT). The sand, used to qualify "baseline" physical and chemical hydrodynamics, was cleaned in a Branson 2510 water bath sonicator (Branson Ultrasonic, Danbury, CT). The cleaning procedure consisted of 1 hour in the sonicator, stirring every 5 minutes followed by a rinse with approximately $10 \mathrm{~L}$ of nanopure water. The sand was air-dried at an average room temperature of $23^{\circ} \mathrm{C}$.

The fresh soil was collected from the top $15 \mathrm{~cm}$ of a small-scale vegetable garden, dried at $108^{\circ} \mathrm{C}$ overnight and passed through a \#10 sieve. All particles less than $2.0 \mathrm{~mm}$ in size were used for the study. This soil was chosen for its high organic material content, minimal weathering and no chemical applications (e.g. no chemical fertilizer, pesticide or herbicide use).

The aged soil was collected from a commercial agricultural farm located in southern California. Five surface soil samples were collected over the 0-30 cm depth below ground surface and stored in discrete $250 \mathrm{ml}$ polypropylene bottles. These field samples were collected from five random locations of a $0.32 \mathrm{~km}^{2}$ rectangular plot (approximately $800 \mathrm{~m}$ by $400 \mathrm{~m}$ ). For use in this study, these five samples were combined, air dried at room temperature for not less than 5 days in a fume hood to avoid settling of ambient dust, thoroughly mixed and passed through a \#10 sieve to remove the greater than $2.0 \mathrm{~mm}$ size fraction. These field-collected agricultural soils herein referred to as "aged soils", have had over 20 years of annually land-applied biosolids as a fertilizer for the commercial farming of cattle feedstock. Additionally, as part of normal farming operations at the site, these soils have received repeated and multiple flood irrigation using wastewater effluent from the local wastewater treatment plant.

\subsection{Analytical Instrumentation:}

\subsubsection{Flame AAS}

Copper standards, ranging from $0.1-10 \mathrm{mg} \mathrm{Cu}^{2+} / \mathrm{L}$, were freshly diluted (within 6 hours of reading on Shimadzu AA-7000 Flame Atomic Absorption Spectrophotometer (AAS)) from a $200 \mathrm{mg} \mathrm{Cu}^{2+} / \mathrm{L}$ stock prepared with $\mathrm{CuCl}_{2}$ (Aldrich Chemicals, CAS\# 10125-13-0, ACS grade), nanopure water and acid fixed with nitric acid (Fisher Scientific, CAS\# 7697-37-2, Trace Metals Grade). Acid fixing 
the solution lowers the $\mathrm{pH}$ to ensure the copper ions stay in solution thereby keeping the aqueous copper concentration of the stock solution accurate. Unless otherwise noted, all dilutions of samples and standards in preparation for reading on AAS were made by mass using an analytical balance with a synthetic rainwater (RW, described in section 2.4). To calibrate the AAS, a line search/beam balance was conducted using the highest readable standard. The burner height of the AAS was set to $7 \mathrm{~mm}$ for copper and $9 \mathrm{~mm}$ for iron according to Shimadzu AA-7700 manual. The same aliquot of RW used for dilutions was also used as a blank to allow for baseline and drift corrections associated with potential background readings from samples. Additionally, analysis of the RW solution as a "blank" ensures there is no contamination of the reagents with the target constituent and indicates the presence of other substances that may cause interference with target readings. Blanks and a mid-range standard were read every 10 samples on analysis to correct for drift as needed. Between samples, $0.017 \mathrm{M} \mathrm{HNO}_{3}$ and/or nanopure water were used to flush the sampling probe and tubing of the AAS. The dilute acid was used to prevent the copper from precipitating and clogging the tubing. Nanopure water was used to flush the acid to prevent corrosion in the instrument.

\subsubsection{Solution $\mathrm{pH}$}

The $\mathrm{pH}$ readings for were taken using either a Hanna Instruments model 98190-pH meter with a Hanna Instruments probe (H12963) or an Orion model 420A pH meter with a VWR SympHony double junction, semi-micro $\mathrm{pH}$ probe (cat\# 89231-592). The semi-micro probe allowed for $\mathrm{pH}$ readings immediately off the column in the narrow diameter, fraction collector tubes. A 2-point calibration of $\mathrm{pH} 4.01$ and $\mathrm{pH} 7.01$ was performed prior to reading samples. The $\mathrm{pH}$ probes were rinsed between samples with nanopure water.

\subsubsection{PFBA Detection}

Pentafluorobenzoic acid (PFBA, Alfa Aesar, CAS\# 602-94-8, 99\%) concentrations were detected on a Hitachi U-1800 UV-Vis spectrophotometer at a wavelength of $226 \mathrm{~nm}$ using quartz cuvettes with a $10 \mathrm{~mm}$ path length. A series of standards were diluted by weight in RW (see section 2.4) from a $525 \mathrm{mg} / \mathrm{L}$ stock of PFBA prepared immediately prior to each use, also in RW. The standards ranged from $525 \mathrm{mg} / \mathrm{L}$ to $1.025 \mathrm{mg} / \mathrm{L}$. Each standard was prepared by serial dilution. RW used for dilutions was also used as a blank on the UV-Vis. The quartz cuvette was rinsed with RW twice between each sample and dried with a lint free wipe to prevent cross contamination or dilution of subsequent samples. 


\subsection{Media Characterization}

Particle size analysis was performed on the porous media used in this study by passing approximately $50 \mathrm{~g}$ of well-mixed, dry soil through a series of U.S.A. standard testing sieves (W.S. Tyler Incorporated, Mentor, Ohio) in sizes of 4.75-, 3.35-, 2.00-, 1.18-, 0.425-, 0.150-, and 0.075$\mathrm{mm}$. As part of the standard particle size analysis, the mass of soil retained on each sieve was measured using an analytical balance. All masses for this study were measured on either an analytical balance (Ohaus AX324) from masses $0.0001 \mathrm{~g}$ to $300.0000 \mathrm{~g}$ or a Mettler PJ3600 balance for masses above $300.00 \mathrm{~g}$.

The fraction of organic matter was estimated by mass loss from ignition (heating the soil samples to approximately $550^{\circ} \mathrm{C}$ for 3 hours). This was achieved by weighing $2.0 \mathrm{~g}$ of each fresh and aged soils in triplicate in ceramic crucibles (empty weight of the crucibles also obtained) on the analytical balance. Additionally, $20.0 \mathrm{~g}$ of fresh soil in triplicate were prepared to compare the variation and accuracy of the smaller mass samples. Two samples of sand were prepared also as above at $2.0 \mathrm{~g}$ each, one as clean sand and the second as acid digested sand (a procedure describe in section 2.7. The sand samples were included as controls for this procedure; the acid digested sand should have no mass difference before and after heating and the clean sand should have little or no mass difference. All samples were heated in a muffle furnace to greater than $535^{\circ} \mathrm{C}$ (Thermolyne Corporation, Dubuque, lowa, Model F-1930-1, 17.0 Amps) for approximately 3 hours. The temperature was checked using a Cen-tech Infrared Thermometer 60725, which has a max temperature reading of approximately $535^{\circ} \mathrm{C}$. During the 3 hours of heating, the furnace temperature was maintained above the range capable of the thermometer. The standard procedure indicates the crucibles should be placed on a tray and turned halfway through the 3 hour heating. There was not enough room in the furnace for a tray so the samples were not turned. Instead, one sand sample (representing the control) was placed by the door and the other at the back of the furnace to capture any differences in heating within the furnace. The other duplicate samples were also split between the front and back of the furnace and their position noted. After heating, all of the samples were allowed to cool completely and weighed again. Since clay can release water at temperatures above $550^{\circ} \mathrm{C}$ and this would affect the organic matter estimate, a clay factor was subtracted from the mass difference pre- and post-heating. This clay factor used to determine structural water loss was calculated from results of particle size analysis as $7 \%$ of particles passing through the \#200 sieve (smaller than 0.075-mm) (Hoogsteen et al. 2015). 


\subsection{Synthetic Rainwater}

Using data collected by Junge and Werby in 1958 that tracked the composition of rainwater around the United States, a recipe for synthetic rainwater was developed for Southern California (Junge \& Werby, 1958) (Junge, 1958). Five hundred milliliters of rainwater were made as a 1000X stock. All reagents for this stock were ACS grade and from Fisher Scientific except as noted (Table 1). Nanopure water was aerated to achieve a pH of approximately 6.0. Aerated water was made by placing 3 to $10 \mathrm{~L}$ nanopure water (Barnstead NANOpure-DiamondTM system-Model No. D11901) in an open carboy on an IKA-VIBRAXVXR orbital shaker overnight. The shaking was just vigorous enough to break the surface tension while avoiding excessive splashing. The 1000X rainwater stock was diluted to $1 \mathrm{X}$ as needed with aerated water. This $1 \mathrm{X}$ synthetic rainwater (RW) was the basis for all the solutions used in this study.

Table 1 : Reagents for $1000 X$ southern California rainwater (RW) stock. Final volume $500 \mathrm{ml}$ in aerated nanopure water. Sourced from Fisher Scientific and ACS grade except where noted.

\begin{tabular}{|c|c|c|c|c|c|c|}
\hline Reagent & $\left(\mathrm{NH}_{4}\right)_{2} \mathrm{SO}_{4}$ & $\mathrm{Ca}\left(\mathrm{NO}_{3}\right)_{2}{ }^{*} 4 \mathrm{H}_{2} \mathrm{O}$ & $\mathrm{Na}_{2} \mathrm{SO}_{4}$ & $\mathrm{NaNO}_{3}$ & $\mathrm{~K}_{2} \mathrm{SO}_{4}$ & $\mathrm{KCl}$ \\
\hline Mass (g) & 0.6607 & 0.8838 & 0.3164 & 0.3234 & 0.5546 & 0.0975 \\
\hline Source & & & Sigma & & Alfa Aesar & Mallinckrodt \\
\hline Purity & & & & & $\begin{array}{r}99.99 \% \\
\text { metals } \\
\text { basis }\end{array}$ & \\
\hline
\end{tabular}

\subsection{Rainwater Batch Tests}

To qualify potential interference on the AAS of water-extractable materials present in rainwater/soil solutions, batch experiments were conducted in triplicate with fractions of fresh soil saturated with rainwater. Four conditions were analyzed in triplicate; $\mathrm{RW}$ at normal pH (e.g. RW made with aerated nanopure water and no further $\mathrm{pH}$ adjustment), $\mathrm{RW}$ adjusted to approximately $\mathrm{pH} 2.0$ using nitric acid (Fisher Scientific, CAS\# 7697-37-2, Trace Metals Grade), RW with fresh soil, and $\mathrm{RW}$ at pH 2.0 with fresh soil. Nalgene bottles ( $250 \mathrm{ml}$ volume) were used for all four conditions. For the conditions with soil, $10 \mathrm{~g}$ of fresh soil (dried and sieved as previously described) were weighed into the bottles. For all conditions, $250 \mathrm{ml}$ of RW solution was added by weight to the bottles (assuming RW density $=1.0 \mathrm{~g} / \mathrm{ml}$ ). The bottles were placed horizontally on an orbital shaker table (Lab-line Orbit Shaker Bath (model 3540)) set at 225 rpm for approximately 34 hours at room temperature. Following the $\sim 34$-hr contact time, the samples were filtered by gravity flow 
through Whatman 40 filters into clean $250 \mathrm{ml}$ Nalgene bottles. Each processed RW sample was used to dilute a known copper stock to be analyzed on the AAS to determine if dissolved OM interfered with the copper absorption reading.

\subsection{Miscible-displacement Experiments:}

\subsubsection{Column Packing}

A search of the literature for column materials used for evaluating copper transport revealed that, when mentioned, plastic was used more often than glass (Hu et al. 2010; Kumar et al. 2013; Garrido-Rodriguez et al. 2014). When glass was indicated, the same research group switched to plastic in more recent studies (Paradelo et al. 2011; Garrido-Rodriguez et al. 2014). Therefore, the columns were constructed of acrylic (Soil Measurement Systems, custom flow cells) and were 7 $\mathrm{cm}$ in length and $2.5 \mathrm{~cm}$ in internal diameter. All experiments were conducted using plastic materials (e.g. tubing, connectors/endcaps and distribution plates were made of polypropylene, nylon and acrylic, respectively).

Each column was dry packed from bottom to top (same direction as flow). The bottom end of the column apparatus was attached and a fine nylon mesh placed between the distribution plate and the open end of the column. This prevented the media from moving through the holes in the distribution plate (nylon mesh was used at both top and bottom open ends of the column). Three small scoops of well mixed media were added to the column, mixing the media every time a scoop was taken. This media was gently tamped down with just the weight of a metal tamping rod (1040.8g). Before use, the tamping rod was cleaned with steel wool, wiped with a damp towel, and dried immediately. This tamped layer was then gently scored (less than $1 \mathrm{~mm}$ depth) with a stylus in a radiating star shape with each line (5 or 6 lines in total for each layer) beginning in the center of the column and moving out toward the edge. This was to key in the next layer. Each media layer was not more than $2 \mathrm{~mm}$ thick (Lewis \& Sjostrom, 2010). This pattern of three well-mixed scoops, gentle tamping and scoring was repeated to fill the column. The final layer was not scored and was flush with the end of the column. The top piece of fine nylon mesh was place on top of the final media layer (overlapping the sealing gasket of the column) and the top distribution plate and column end were tightened in place. Figure 1 shows the tools used to pack the columns. 


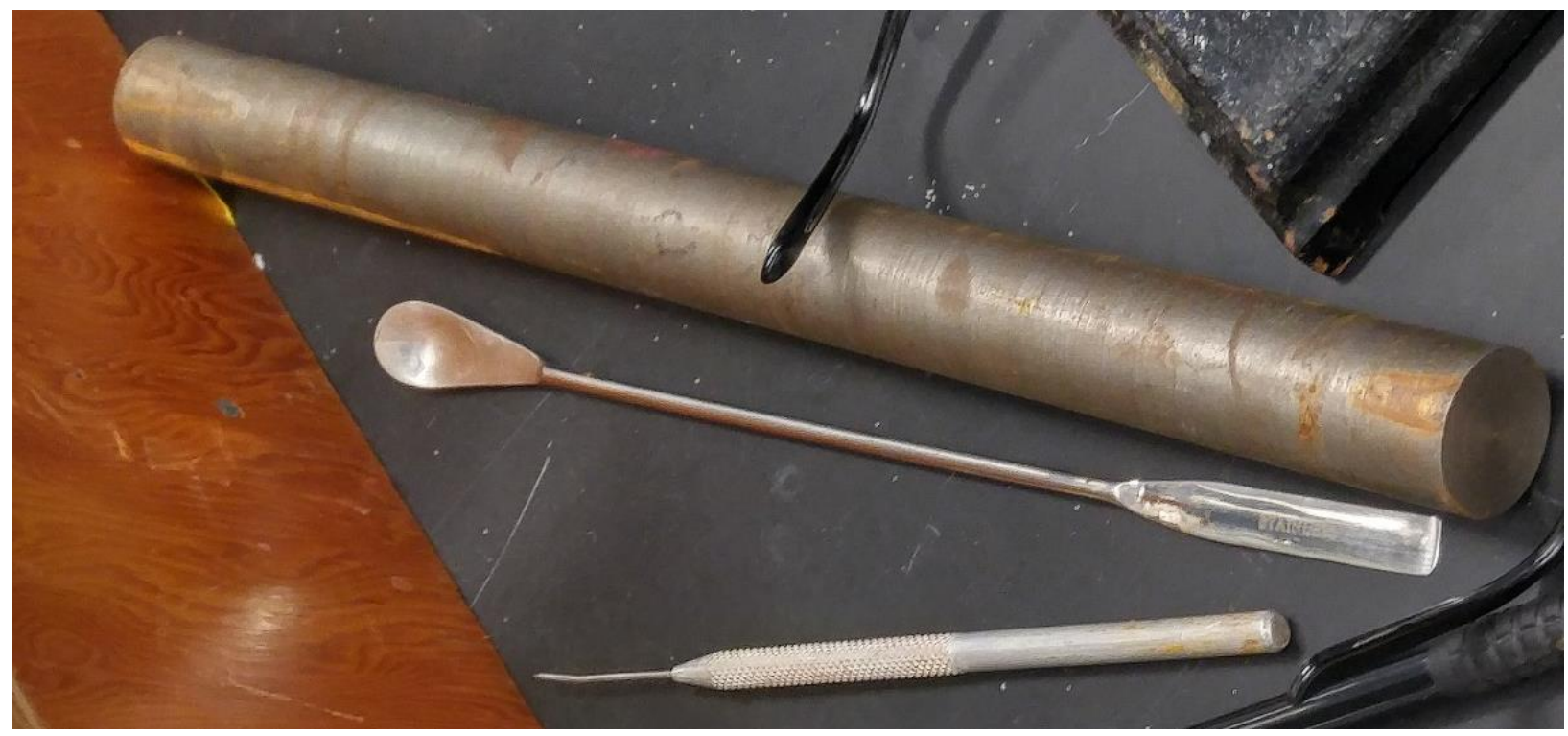

Figure 1: Tools used for packing columns. From top to bottom: tamping rod, scoop, and stylus.

After the columns were pack, they were connected to a High Performance Liquid Chromatography (HPLC, Acuflow Series II) pump to saturate the porous media with RW. The fluid was injected through the bottom of the column and eluted through the top to reduce preferential flow paths and to encourage an evenly distributed wetting front through the saturating porous matrix. Saturation of the porous matrix included $0.25 \mathrm{ml} / \mathrm{min}$ fluid flow for approximately 24 hours, followed by 0.35 $\mathrm{ml} / \mathrm{min}$ for approximately 24 hours, and finally $0.5 \mathrm{ml} / \mathrm{min}$ for a minimum of three days. Each day the column was weighed. Once the weight of the column remained unchanged for several consecutive days, the column was considered fully saturated.

\subsubsection{Non-Reactive Tracer Studies}

To characterize the physical hydrodynamics of the media, a non-reactive tracer, pentafluorobenzoic acid (PFBA, Alfa Aesar, CAS\# 602-94-8, 99\%), at a concentration of $500 \mathrm{mg} / \mathrm{L}$ in RW was injected into the columns using an FMI Lab Pump model QG 6 (Q-pump) set to a flow rate of approximately $0.5 \mathrm{ml} / \mathrm{min}$ and the eluate was analyzed by UV-VIS spectrophotometer. Samples were diluted as necessary with RW by weight on the analytical balance. Once the system achieved complete breakthrough of PFBA (i.e. the concentration of the eluate $(\mathrm{C})$ reached the same concentration as the injection solution $\left(C_{0}\right)$ ) the columns were eluted with PFBA-free RW. 


\subsubsection{Trace Metal Studies}

The copper concentration for the copper injection solution was calculated by determining the lowest detection limit for copper on the Flame Atomic Absorption Spectrophotometer (AAS) and setting the copper concentration for the solution at three orders of magnitude above this lowest detection limit. The lowest detection limit was observed to be $0.1 \mathrm{mg} \mathrm{Cu}{ }^{2+} / \mathrm{L}$; therefore, the concertation for the copper injection solution was $100 \mathrm{mg} \mathrm{Cu}^{2+} / \mathrm{L}$ in $\mathrm{RW}$ using $\mathrm{CuCl}_{2}$ (Aldrich Chemicals, CAS\# 10125-13-0, ACS grade). A portion of this solution, achieving a $\mathrm{pH}$ of 4.9 on equilibration, was $\mathrm{pH}$ adjusted to either approximately 2 using nitric acid (Fisher Scientific, CAS\# 7697-37-2, Trace Metals Grade) or to approximately 6 using sodium hydroxide (EM Science, CAS\# 1310-73-2, heavy metals $<0.01 \%$ and iron 5 ppm). Upon adjusting the solution to $\mathrm{pH} 6$, a precipitate formed. Analysis of the copper solution filtrate (filtered using an Advantec syringe filter composed of mixed cellulose ester, 0.45 um pore size) suggested that approximately $25 \%$ of the copper in the copper pH 6 solution was precipitated. The solution was used 'as is' (e.g., with approximately $75 \mathrm{mg} \mathrm{Cu}^{2+} / \mathrm{L}$ ) for the column studies.

A second injection solution consisting of a mix of trace metals was formulated based on the irrigation water used in the fields where the aged soils were collected. Specifically, with the copper concentration set at $100 \mathrm{mg} \mathrm{Cu}^{2+} / \mathrm{L}$, as described above, the remaining prevalent trace metals found in the irrigation water were added, maintaining the same relative molar ratios to copper in solution as in the original irrigation water. Table 2 shows the initial concentrations of the metals in the irrigation water, the molar ratios, the scaled up concentrations and the reagents used to make the mixed trace metals solution.

Table 2 : Concentrations and molar ratios of irrigation water and mixed trace metal solution.

\begin{tabular}{r|rrrr} 
& $\mathbf{Z n}^{2+}$ & $\mathbf{F e}^{3+}$ & $\mathbf{C u}^{2+}$ & $\mathbf{M n}^{2+}$ \\
\hline Initial Concentration (ug/L) & 48 & 73 & 3.4 & 15 \\
Molar Ratio & 0.31 & 0.55 & 0.02 & 0.12 \\
Injection Solution (mg cation/L) & 1410 & 2150 & 100 & 441 \\
Chemical Formula & $\mathrm{ZnCl}_{2}$ & $\mathrm{FeCl}_{2}{ }^{*} 6 \mathrm{H}_{2} \mathrm{O}$ & $\mathrm{CuCl}_{2}$ & $\mathrm{MnSO}_{4}{ }^{*} \mathrm{H}_{2} \mathrm{O}$ \\
Source/Purity & Mallinckrodt/ & Acros Organics/ & Aldrich & J.T. Baker/ \\
& ACS grade & $99+\%$ extra pure & Chemicals/ & ACS grade \\
& & & ACS grade &
\end{tabular}


During the experiments, automated fraction collectors (Teledyne ISCO, Retriever 500 and SpectrumLabs.com, Spectra/Chrom Fraction Collector CF-2) were utilized to collect fractions of the column effluent. The flow rate for each column was checked periodically by weighing specific collection tubes prior to collection as well as after collection for a known amount of time. These samples were analyzed for copper, iron, and $\mathrm{pH}$. Once complete breakthrough of copper was achieved $\left(C / C_{0}=1\right)$, the columns were eluted with metal-free RW.

\subsection{Modified ISO11466.3 Acid Digest}

To determine the total copper content, the soils were acid digested at various stages during the experiments (unexposed and exposed to copper or mixed trace metals). Acid digestion of soils breaks down organic matter to release most bound trace metals (including copper and iron) to the soluble phase. Once the trace metals are in the soluble phase the total concentration can be determined. The original ISO11466.3 protocol (Pena-lcart et al. 2011) was modified to use $20 \mathrm{ml}$ acid solution to digest $1 \mathrm{~g}$ soil, instead of $40 \mathrm{ml}$ per $1 \mathrm{~g}$ soil as in the original protocol. The results of this modified method were compared to the results obtained by an independent lab that used the EPA 3050b digestion protocol. The differences between the results of the two protocols were insignificant. The acid solution/mix consisted of final concentrations of $9 \mathrm{M} \mathrm{HCl}$ (BDH, CAS\#764701-0, ACS grade) and 4.25 $\mathrm{M} \mathrm{HNO}_{3}$ (Fisher Scientific, CAS \# 7697-37-2, trace metals grade). This ratio of acids was obtained by mixing concentrated acids (no water was added to make the acid $\mathrm{mix}$ ). One gram of soil was weighed on the analytical balance in a $250 \mathrm{ml}$ Erlenmeyer flask. To this, $20 \mathrm{ml}$ by volume of the acid mix was added using a glass pipette. This mixture was allowed to sit in a fume hood at room temperature for 24 hours covered by a ribbed watch glass. After this incubation while still in the fume hood, the flask was heated at $130{ }^{\circ} \mathrm{C}$ for $15 \mathrm{~min}$ on an aluminum heater (Central Scientific, Cenco Instruments Corporation, Cat\# 16674), then allowed to cool. The use of a $250 \mathrm{ml}$ Erlenmeyer flask was important during the heating step to allow the mixture to bubble and expand without loss of the sample. This cooled mixture was filtered to remove all particles using a Whatman ashless 41 filter (Cat\# 1441 110). The filtrate was collected in an acidwashed $100 \mathrm{ml}$ volumetric flask. The $250 \mathrm{ml}$ Erlenmeyer flask and the filter were rinsed well with $0.17 \mathrm{M} \mathrm{HNO}_{3}$ into the volumetric flask to collect all the extracted trace metals. Great care was taken to fill the remainder of the $100 \mathrm{ml}$ volumetric flask with $0.17 \mathrm{M} \mathrm{HNO}_{3}$ so the meniscus corresponded to the etched volume line. Adequate mixing of the sample in the $100 \mathrm{ml}$ volumetric flask was ensured, and the sample was analyzed on the AAS to determine total copper concentration. 
As an example of the application of this procedure, the copper solution at $\mathrm{pH} 6$ was injected into two fresh soil columns in parallel for approximately 40 pore volumes. There was no detectible copper present in the eluate of either column at that time $\left(\mathrm{C}_{\mathrm{f}} / \mathrm{C}_{0}=0\right.$; final concentration divided by initial concentration). The columns were unpacked, maintaining the soil core as one piece and the orientation marked. After drying, the core was divided according to placement within the column. Each section was discretely well mixed, and a subsample analyzed for copper content by acid digest.

\subsection{Data Analysis}

Analysis of sample concentrations for both copper and PFBA on the AAS and the UV-VIS, respectively, started with a linear regression of the absorbance values versus the known concentrations of the standards. The sample concentrations were then calculated by substituting the sample absorbance readings into the linear equation generated. For iron, sample values were a ratio of sample absorbance to the absorbance of the initial injection solution. Dilutions were taken into account when calculating the final concentrations. 


\subsection{RESULTS AND DISCUSSION}

\subsection{Rainwater Batch Tests}

Figure 2 shows the results of the rainwater batch tests wherein the effects of the leachate from the fresh soil on copper concentration readings become apparent. The percent difference (\% diff) on the $y$-axis refers to the difference between the copper concentration determined by the AAS measurement (by linear regression of standard curve) for the sample and the calculated amount of copper in the sample based on mass of stock solution used and how much it was diluted.

$$
\% \text { diff }=(\text { calculated-AAS }) / \text { calculated * } 100
$$

Therefore, a positive percent difference indicates sample appears to contain less copper by AAS, while a negative percent difference indicates the sample appears to contain more copper by AAS.

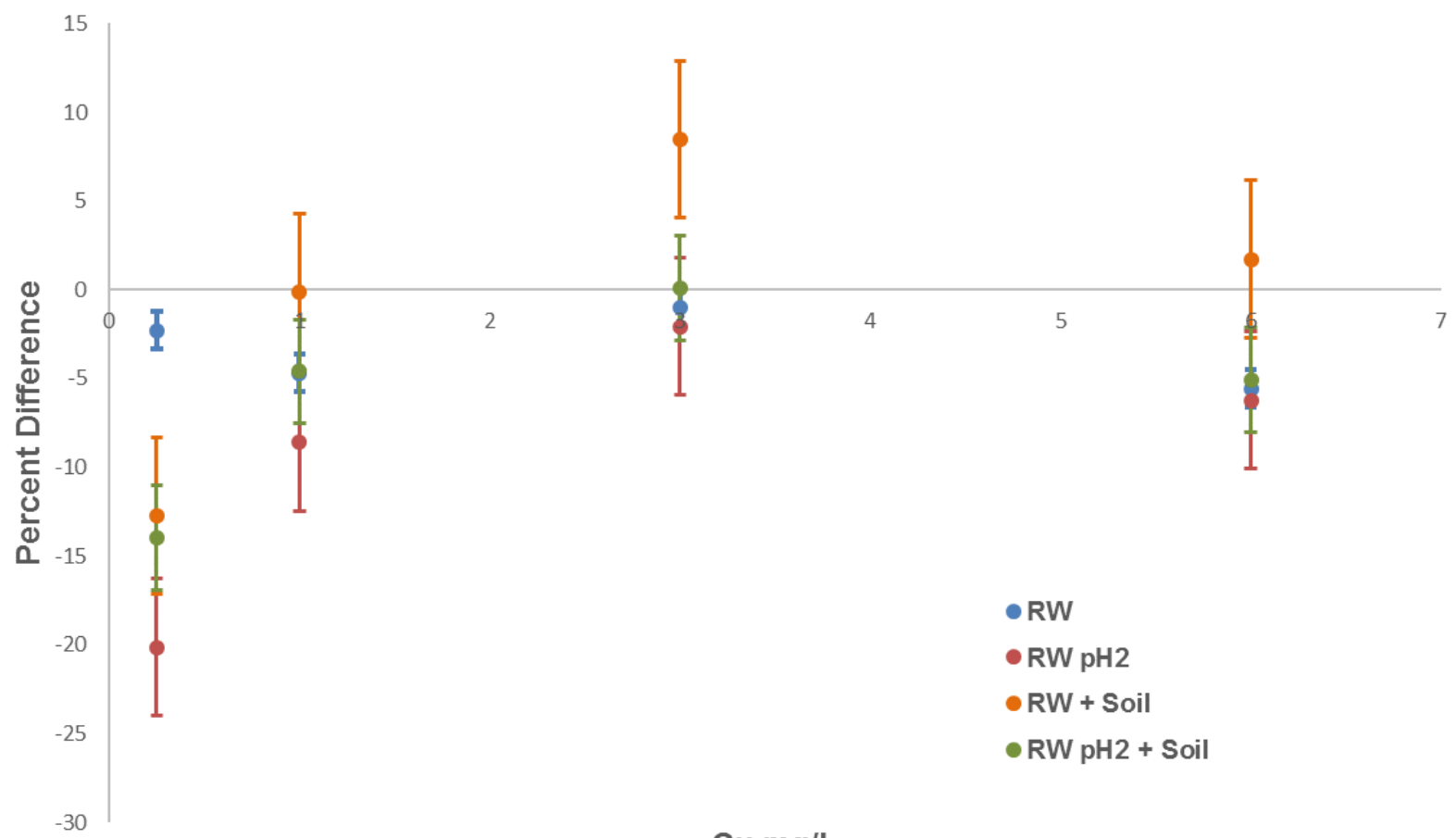

Cu mg/L

Figure 2: Effects of leachate from fresh soil on copper concentration readings. 
The contact time of 34 hours, was determined by the amount of time it took for copper to arrive in the eluate of $\mathrm{pH} 2.2$ solution (see section 3.5, Figure 11). The volume of RW was similarly decided upon (e.g. similar proportions of solution volume in 34 hours to mass of soil in column).

Except for the readings of the lowest concentration, $0.25 \mathrm{mg} \mathrm{Cu} / \mathrm{L}$, most of the samples are within $10 \%$ difference of the calculated copper concentrations. This suggests that soluble components from the fresh soil (e.g. dissolved organic matter in solution) have negligible impact on the detection of copper in solution using AA-flame for concentrations above $1 \mathrm{mg} \mathrm{Cu} / \mathrm{L}$. These soluble components do impact the response reading of the AA-flame for lower concentrations of copper making the samples at low concentration appear slightly more concentrated. Therefore, experimental samples (e.g., eluates from the column studies) with concentrations above the linear range of the AAS ( $~ 8 \mathrm{mg} \mathrm{Cu/L)}$ were diluted for analysis on the AAS to the 3-6 $\mathrm{mg} \mathrm{Cu} / \mathrm{L}$ range and samples reporting below $1 \mathrm{mg} \mathrm{Cu} / \mathrm{L}$ were reported as outside of the measureable detection limit of the AAS.

\subsection{Solution Chemistry}

The ion composition in the copper solution was evaluated using Visual Minteq 3.1 (13 DEC 2016 Jon Petter Gustafsson, KTH, SEED, Stockholm, Sweden) to determine copper speciation over a $\mathrm{pH}$ range of 1.0 to 7.0 (see Figure 3) Saturation Index (SI) is the log of the lon Action Product (IAP) minus the log of the solubility constant (Ksp).

$$
S I=\log (I A P)-\log (K s p)
$$

For $\mathrm{SI}<0$, the compound remains in solution. For $\mathrm{SI}>0$, the compound is likely to form a precipitate. At $\mathrm{SI}=0$, the compound is at equilibrium. As shown in Figure 3, everything below the $x$-axis is in solution and everything above the $x$-axis is precipitating. There are three primary groups of precipitates forming; at $\mathrm{pH} 5.3, \mathrm{pH} 5.7$, and $\mathrm{pH}$ 6.2. The $\mathrm{pH}$ range of rainwater in the environment is 4.6- 6.4 and more commonly 5.7-6.2, the $\mathrm{pH}$ range where most of the compounds are precipitating in this copper solution. When initially mix, at equilibrium, this solution has a $\mathrm{pH}$ of 4.9. This copper solution was used in column assays at the unadjusted $\mathrm{pH}$ as well as adjusted to $\mathrm{pH} 6.0$ to mimic current agronomic practices (maintain soil $\mathrm{pH}$ above 6.0 ) and to $\mathrm{pH} 2.2$, which was similar to the mixed metals solution. 


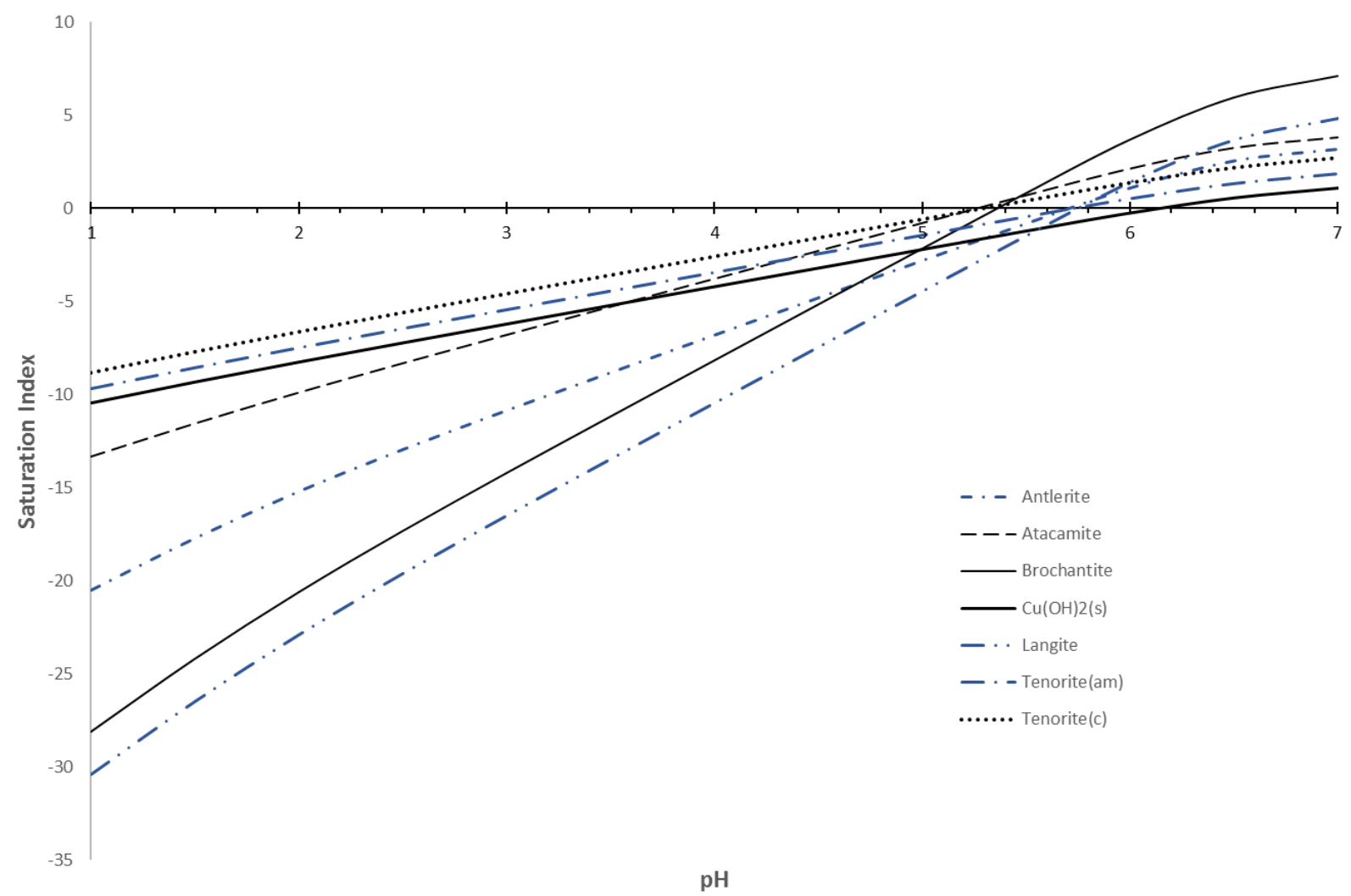

Figure 3: Chemical analysis of ion in copper only solution using Visual Minteq software.

When initially mixed, the mixed trace metals solution had a $\mathrm{pH}$ of approximately 1.7-2.0 with no $\mathrm{pH}$ adjustment. The precipitates predicted by Visual Minteq (Figure 4) in this low pH range appear to be suspended solids since no settled precipitates were observed in the solution after days of sitting at room temperature. 


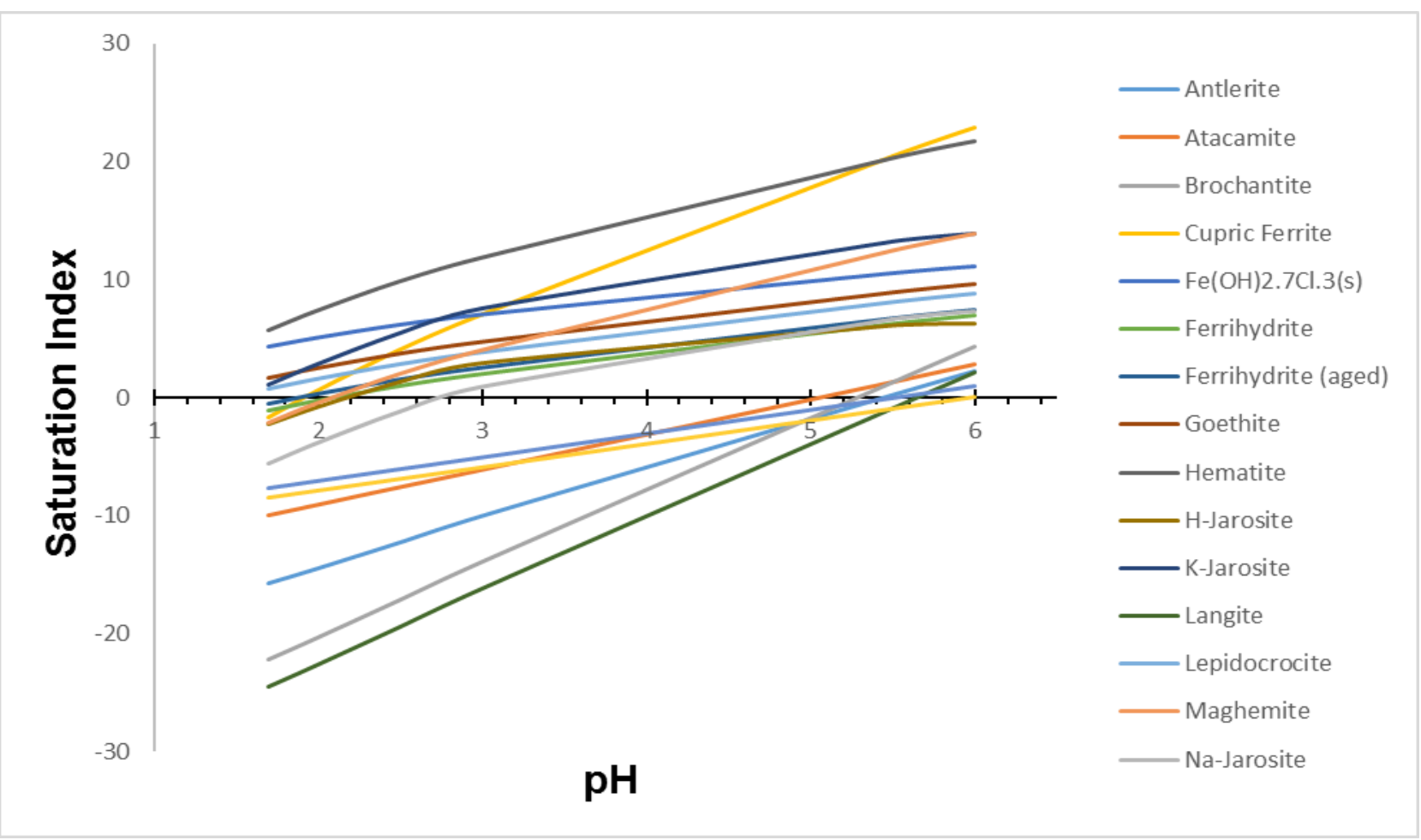

Figure 4: Chemical analysis of ion in mixed trace metals solution using Visual Minteq software

A portion of the mixed trace metals solution was $\mathrm{pH}$ adjusted to $\mathrm{pH} 5.7$ with $\mathrm{NaOH}$ and a gelatinous precipitate formed and settled. The remaining aqueous portion, after the precipitate settled, was tested on the AAS and found to contain very little copper. In fact, iron chloride can be used as a coagulant in wastewater treatment (Forster, 2003). This mixed trace metals solution at $\mathrm{pH} 5.7$ was determined to be unusable in the columns due to the gelatinous precipitate and the very low metals concentration remaining in the aqueous portion of the solution. Therefore, to see how copper interacts with natural media in the presence of other metals in solution, the mixed trace metals solution at $\mathrm{pH} 1.9$ (unadjusted) was used. The results of the copper solution at $\mathrm{pH}$ 2.2 were compared to these mixed trace metal results to account for the effects of the low pH (see section 3.5).

\subsection{Media Characterization}

Each of the natural porous media were analyzed for content by particle size distribution and organic matter (OM) by ignition (21Figure 5). The cleaned and milled sand contained approximately $0.09 \% \mathrm{OM}$ while the acid digested sand contained approximately $0.06 \% \mathrm{OM}$. The 
two field media had compositions with more complexity. One notable difference between the two that is significant to this study is that the fresh soil had approximately $15 \% \mathrm{OM}$, while the aged soil had $5.0 \%$ OM (average of triplicates). It may be of interest to note, the differences between the percentage of $\mathrm{OM}$ in the $20 \mathrm{~g}$ and $2.0 \mathrm{~g}$ fresh soil samples for ignition were insignificant.

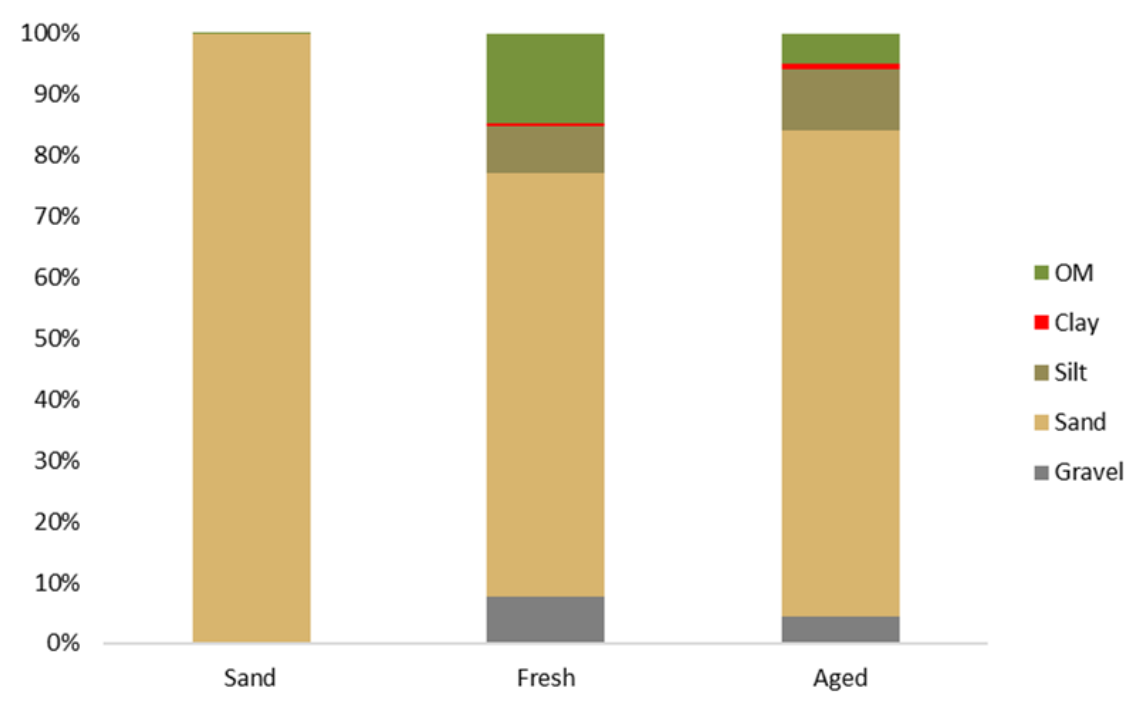

Figure 5: Media composition determined by particle size distribution and organic matter by ignition.

Each of the natural porous media were analyzed by acid digest for copper content (Figure 6). The silica sand (used as the control in this study) had no detectible copper and, furthermore, did not retain any copper after exposure to the mixed trace metals solution as would be expected for a model, silica sand (Table 3). Acid-digestion of the fresh soil, collected from a local, small-scale vegetable garden, yielded $0.04 \mathrm{mg}$ total $\mathrm{Cu} / \mathrm{g}$ soil. The aged soil, collected from a commercial farm following more than 20 years of land-applied biosolids, had approximately $0.13 \mathrm{mg}$ total $\mathrm{Cu} / \mathrm{g}$ soil. 
0.04

0.02

0

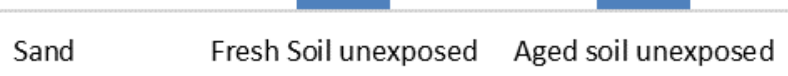

\section{Soil Type}

Figure 6: Copper concentration determined by acid digest on various soils. Sand had no detectible copper.

The results of total copper concentrations measured along the soil column flow-path, from influent to effluent, following approximately 40 pore volumes of copper solution at $\mathrm{pH} 6$ are shown in Figure 7 and listed in Table 3. The majority of the copper was detected in the bottom quarter of the columns (the injection end). The bottom half contained an appreciable amount of copper, while the top half and top quarter contained only slightly more copper than unexposed fresh soil (Table 3). Recall that the solution consisted of approximately $75 \mathrm{mg} \mathrm{Cu}^{2+} / \mathrm{L}$. The remaining $25 \mathrm{mg} \mathrm{Cu} / \mathrm{L}$ precipitated and was filtered by the initial thin nylon mesh at the inlet side of column structure and was prevented from entering the soil matrix. Most of the aqueous copper that entered the column was retained in the bottom layer, where influent enters the column. 


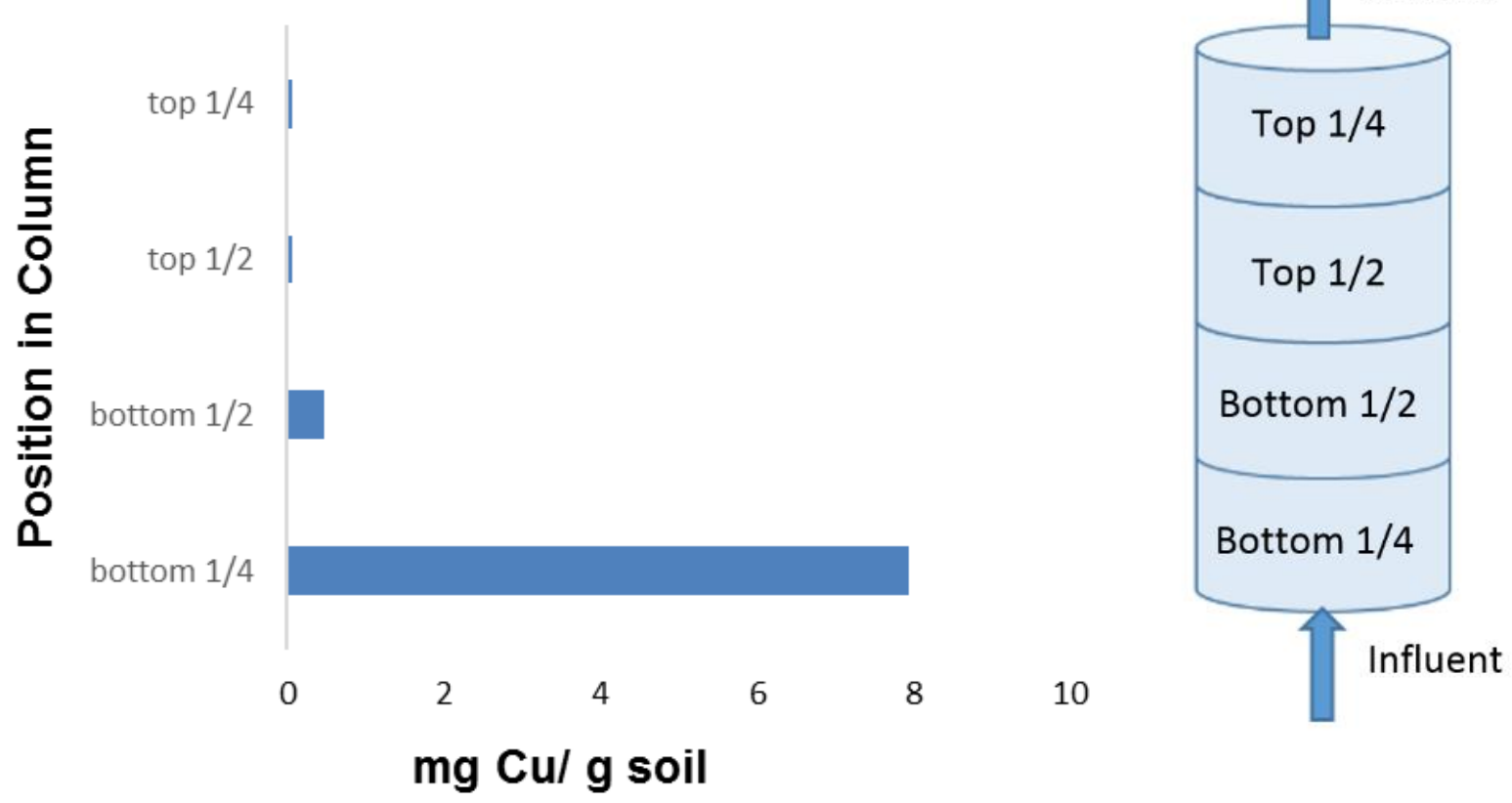

Figure 7: Copper concentration determined by acid digest of fresh soil exposed to copper solution at pH 6.0 for $\mathbf{4 0}$ pore volumes and diagram of the position in the column for each batch sample and direction of flow.

Table 3 : Mass of total copper per gram of soil determine by acid digest arranged by soil type and treatment.

\section{Soil Type Treatment, Location $\quad \mathrm{mg} \mathrm{Cu}^{2+} / \mathrm{g}$ soil}

\begin{tabular}{c|cc}
\hline Sand & Exposed and unexposed & 0 \\
Fresh & Unexposed & 0.040 \\
& Exposed-mixed trace metals & 0.116 \\
& Copper, Top $1 / 4$ & 0.057 \\
& Copper, Top $1 / 2$ & 0.054 \\
& Copper, Bottom 1/2 & 0.461 \\
Aged & Copper, Bottom $1 / 4$ & 7.946 \\
& Unexposed & 0.127
\end{tabular}


In evaluating the data in Table 3, it is important to remember that the fresh soil exposed to mixed trace metal solution had multiple metal ions in solution at $\mathrm{pH} 1.9$, both of which will lower the copper binding in the soil, while the quartered columns were run with copper alone at $\mathrm{pH}$ 6.0. The factors of $\mathrm{pH}$, the percentage of organic matter and additional metal ions all have varying, complex affects the media's ability to sorb copper. What can be gained from this table is that sand does not sorb copper and the unexposed fresh soil has lower copper content than the unexposed aged soil.

\subsection{Nonreactive Tracer Studies}

The results of the PFBA tracer through the sand and fresh soil columns are illustrated in Figure 8. Fifty percent of the arrival of PFBA for both media was at approximately one pore volume and both had complete breakthrough $\left(\mathrm{C} / \mathrm{C}_{0}=1, \mathrm{C}=\right.$ sample concentration, $\mathrm{C}_{0}=$ initial concentration). The non-zero start of the injection of PFBA in the fresh soil was due to interference of organic material eluting from natural porous medium on the UV-VIS at $226 \mathrm{~nm}$. This is similar to the low-range interference on the AAS (as discussed in section 3.1). A blank consisting of RW eluted from the fresh soil column prior to the injection of the PFBA confirmed this interference, which only affected measurements at low concentrations. As expected, PFBA in sand illustrated near ideal physical hydrodynamics. The slight variance in the behavior of PFBA in fresh soil was probably due to the natural structure of the garden soil versus the uniform, milled structure of the sand. 


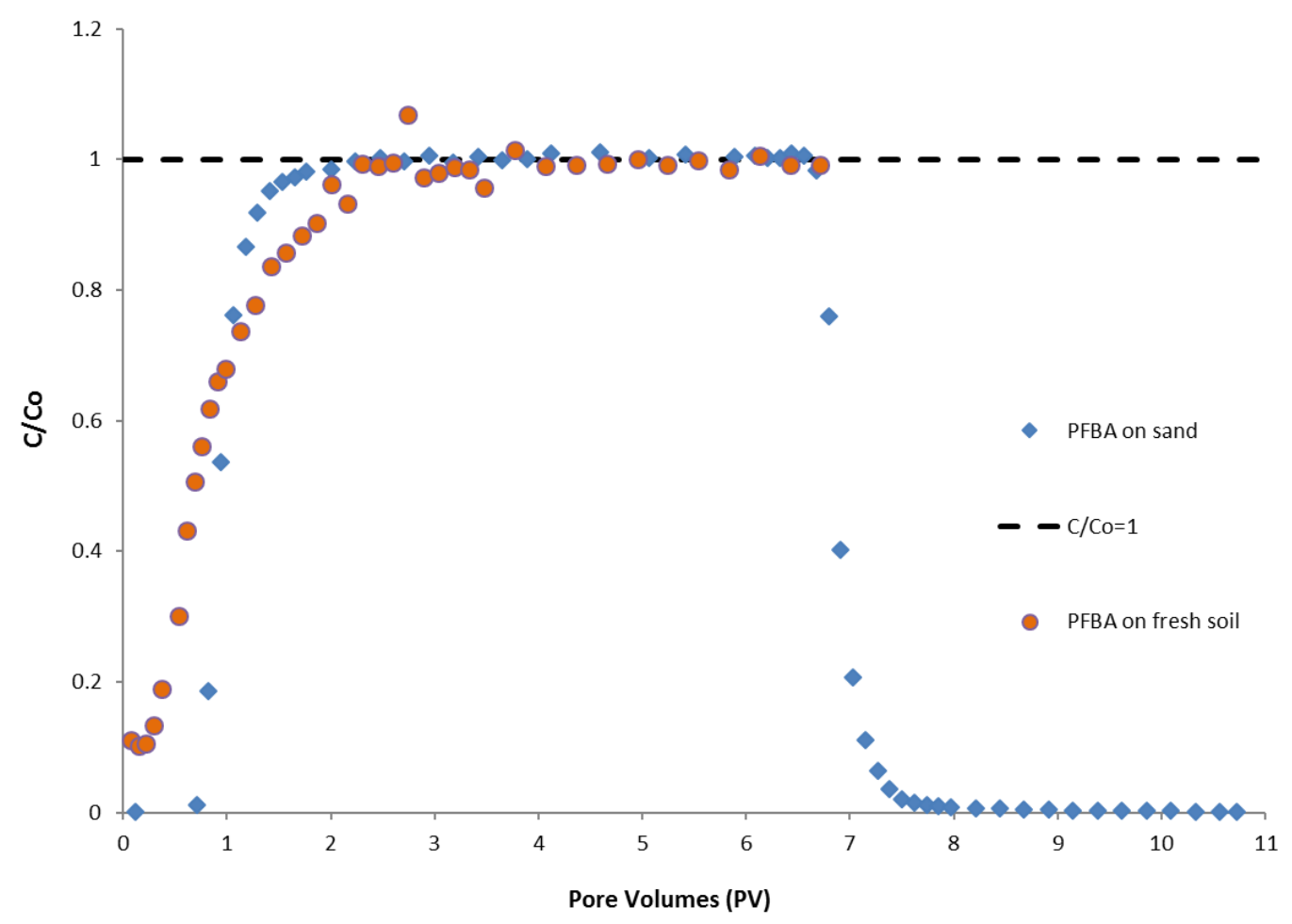

Figure 8: Non-reactive tracer (PFBA) in sand and fresh soil columns.

\subsection{Trace Metal Transport}

A comparison of the arrival of copper using the mixed trace metals solution through sand versus fresh soil is shown in Figure 9 (the nonreactive tracer results for the sand is included for reference). The nearly identical arrival curves of PFBA and copper through sand indicate that no chemical processes are affecting the hydrodynamics of copper transport through the silica sand. Copper's transport is governed only by physical hydrodynamics through silica sand.

While, the movement of copper through sand is governed by physical hydrodynamics, the arrival of copper on the fresh soil was delayed and there was enhanced arrival to a $C / C_{0}>2.0$. The results of the complete injection of mixed trace metals solution on the fresh soil is shown in Figure 10. The delayed and enhanced arrival of copper on the fresh soil (Figures 9 and 10) indicates that chemical hydrodynamics play an important role in copper transport in the fresh soil. 


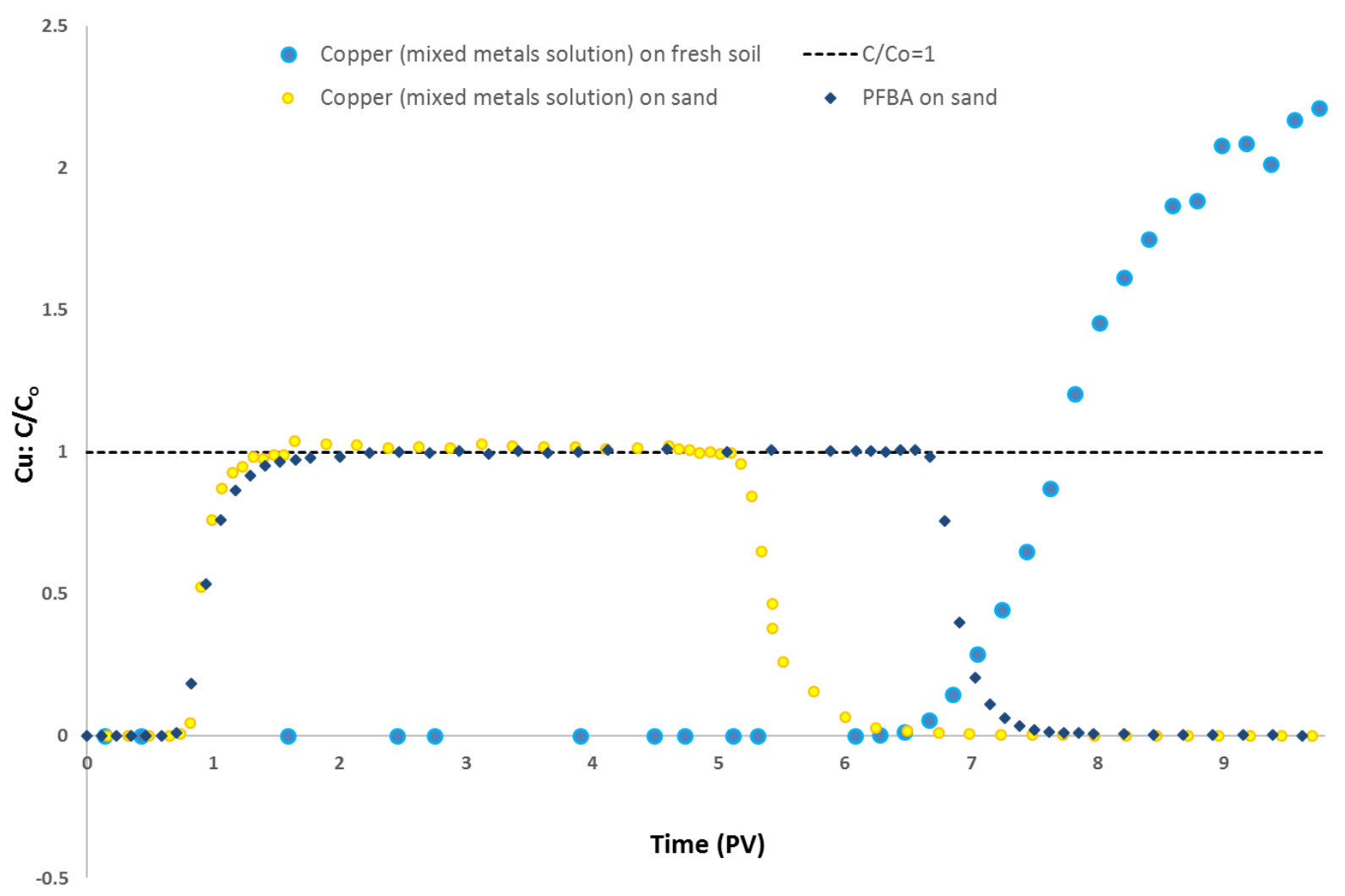

Figure 9: First 10 pore volumes of PFBA and mixed trace metals solution on sand and mixed trace metals solution on fresh soil (measuring copper concentration).

The decision to test for iron as a possible competitor of copper in Figure 10 came from the color of the eluates in mixed trace metals solution on sand (Figure 9). The samples started to turn yellow, potentially indicating the presence of iron. This coincided with an increase in copper concentration. For mixed trace metal solution on fresh soil, this color change of the eluates did not coincide with the change in copper concentrations. This suggested that iron and copper were behaving differently on transport through the various natural media.

In the full breakthrough curve of mixed trace metals solution on the fresh soil (Figure 10), iron arrives first, plateaus with the arrival of copper then increases at a slower-than-initial rate as more copper elutes off the fresh soil column. The enhanced copper concentration peaks at about $\mathrm{C} / \mathrm{C}_{0}=$ 2.2 before quickly decreasing and then slowly settling/plateauing at $C / C_{0}=1$. The settling of copper coincides with the complete breakthrough and plateauing of iron at $\mathrm{C} / \mathrm{C}_{0}=1$. Additionally, as also shown in Figure 10, samples were analyzed for solution $\mathrm{pH}$. The initial $\mathrm{pH}$ is near that of $\mathrm{RW}(\mathrm{pH} \sim 5)$, rises to about 6.7 then falls steadily to the $\mathrm{pH}$ of mixed trace metals solution, $(\mathrm{pH} \sim$ 
2). Upon elution of copper and iron from the fresh soil using metal-free $\mathrm{RW}$, the $\mathrm{pH}$ begins to rebound. Also of interest to note is that the arrival of the metals in the eluate coincides with the drop in $\mathrm{pH}$ of the eluate.

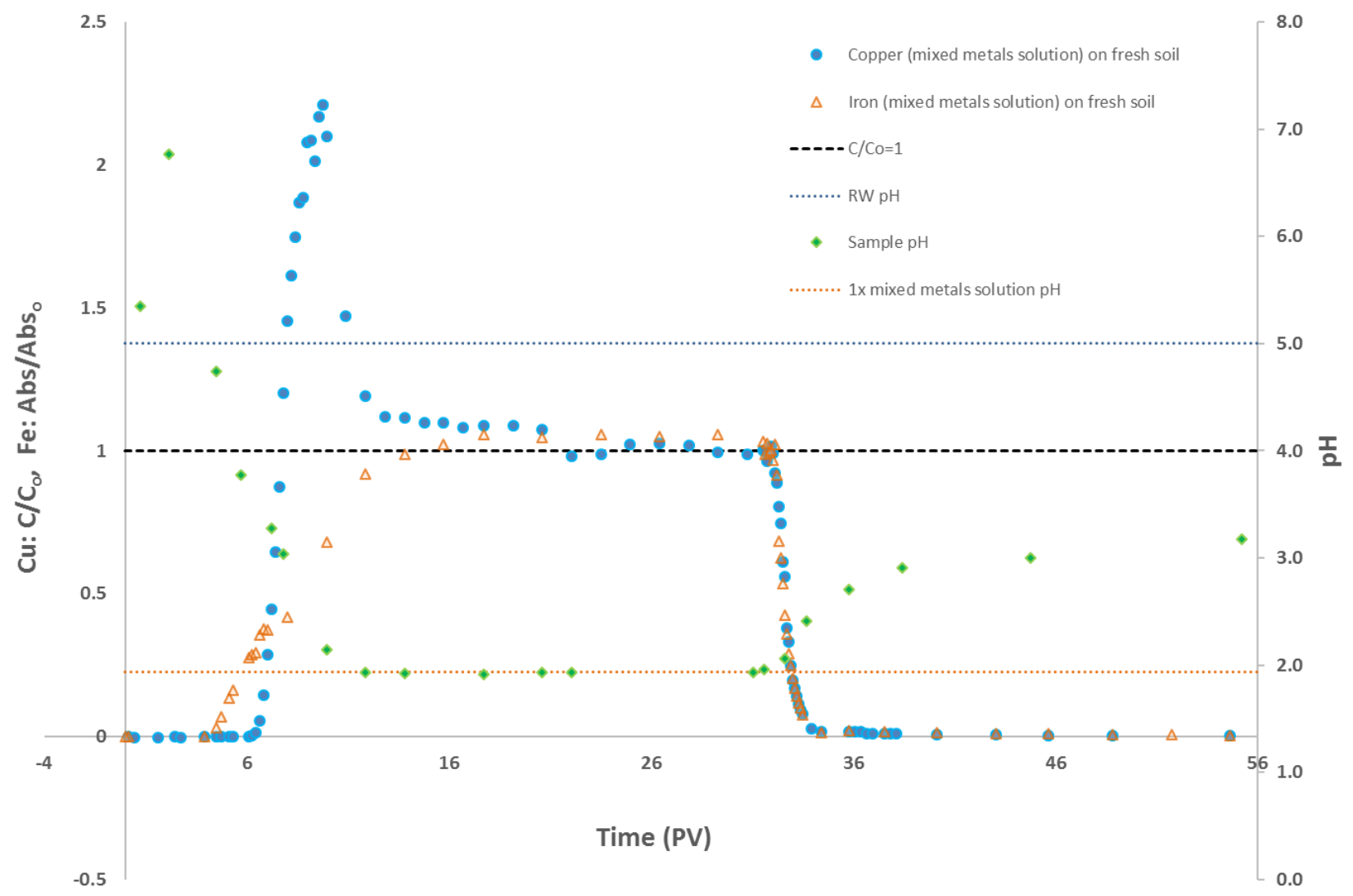

Figure 10: Full curve of mixed trace metals solution on fresh soil showing copper and iron concentrations as well as $\mathrm{pH}$.

In an attempt to separate the effects of mixed trace metals and $\mathrm{pH}$ on the transport of copper in fresh soil, the copper solution at $\mathrm{pH} \sim 2$ was injected on a newly prepared column (results shown in Figure 11). The arrival of copper again coincides with a drop in pH. This is accompanied again by enhanced arrival; copper concentrations in eluate nearly two times higher than copper concentrations in influent. This suggests that the enhanced arrival of copper is due, at least primarily, to the low pH and not due to the presence of competitive metals in solution. The concentrations of eluate and influent do become equal again, although there is a second enhanced arrival after a stop flow episode (at PV 113). Following the stop flow experiment, the $\mathrm{pH}$ also 
increased slightly and then approaches the $\mathrm{pH}$ of the influent again $(\mathrm{pH} \sim 2)$. The stop flow could be allowing the system to recover slightly; soil able to buffer the low $\mathrm{pH}$ influent and thereby affect the soil-copper interactions. Rate-limited mass transfer between the solution and the soil may also account for the lower copper concentrations in the eluate after the stop flow (e.g., during stop flow copper has more time to interact with soil particles and bind, therefore less copper in solution/eluate when flow started again).

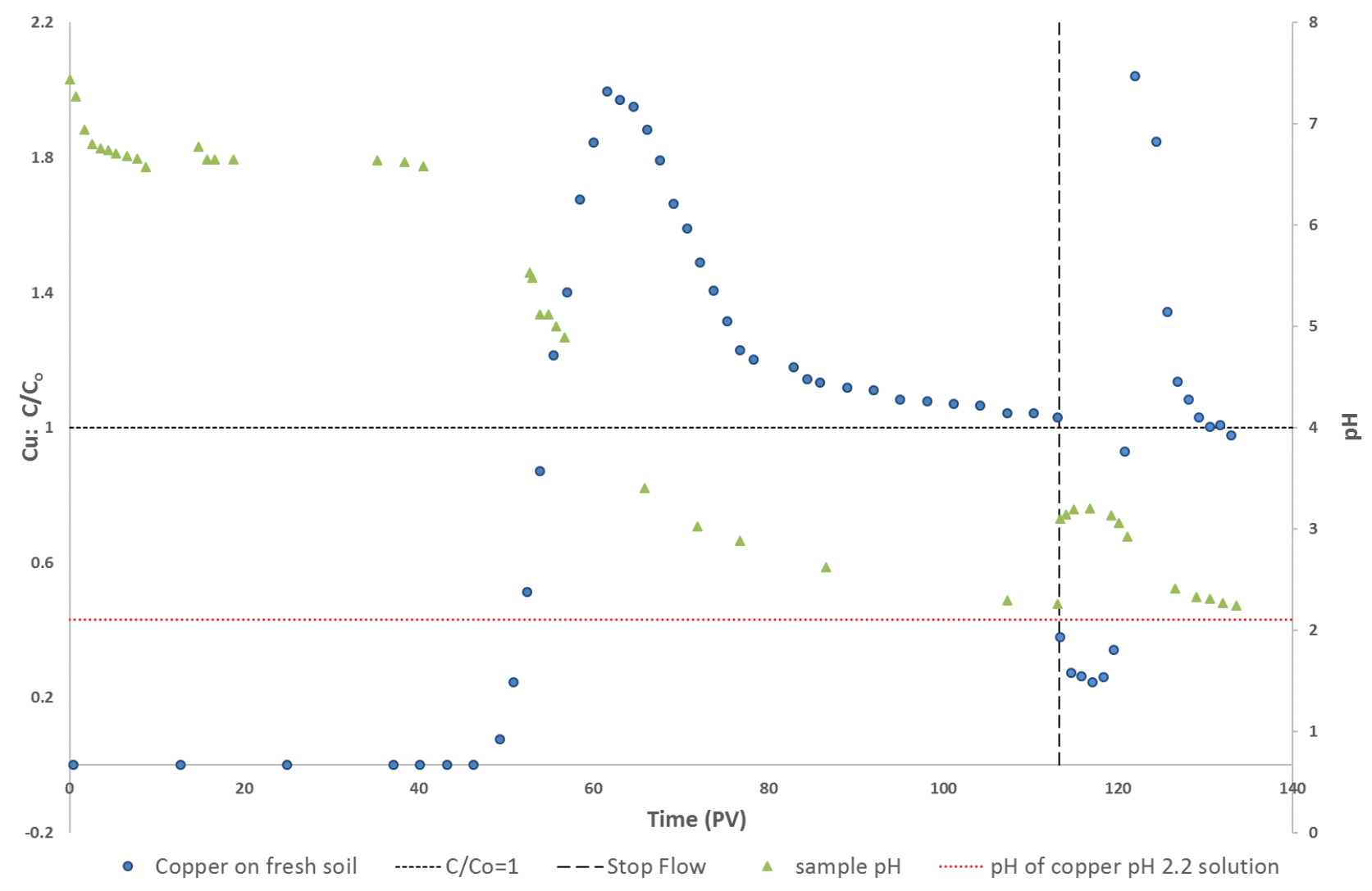

Figure 11: Copper solution at pH 2.2 on fresh soil showing enhanced arrival

Figures 12 and 13 illustrate the behavior of the copper solution at $\mathrm{pH} 4.9$, with sample $\mathrm{pH}$ included, on both fresh and aged soils. The data in Figure 13 are normalized by dividing the pore volumes (PV) by the retardation factor ( $R$, the time it takes, in PV, for the eluate to achieve $50 \%$ of the initial concentration $\left.\left(\mathrm{C} / \mathrm{C}_{0}=0.5\right)\right)$ of each curve to compare the shape of these two curves.

In Figure 12, the vertical lines between pore volumes 30 and 50 indicate times of stop flow for each column. The $\mathrm{pH}$ values of the samples are marked with X's in the corresponding color to the 
copper concentration from the same column. Copper's arrival wave through the aged soil was earlier (at approximately $100 \mathrm{PV}$ ) than it was in the fresh soil (at approximately $160 \mathrm{PV}$ ). These results indicate the fresh soil has significantly greater potential uptake of copper ions than the aged soil. Additionally, the arrival of copper in both columns coincides with a sustained drop in $\mathrm{pH}$ measured in the column effluent.

In Figure 13, the overall shapes of the arrival waves for copper from both soils are compared. In the aged soil, copper shows a degree of early arrival and a more delayed approach to complete breakthrough. The overall transport behavior of copper measured in the aged soil shows more non-ideal transport behavior (early breakthrough and delayed approach to $\mathrm{C} / \mathrm{C}_{0}=1$ ) compared to that measured in the fresh soil.

The trend of the $\mathrm{pH}$ values for both soils is similar though the values for the aged soil were lower than the fresh soil. Also of note is that the $\mathrm{pH}$ of the eluate from both soils dropped below the initial $\mathrm{pH}$ of the influent.

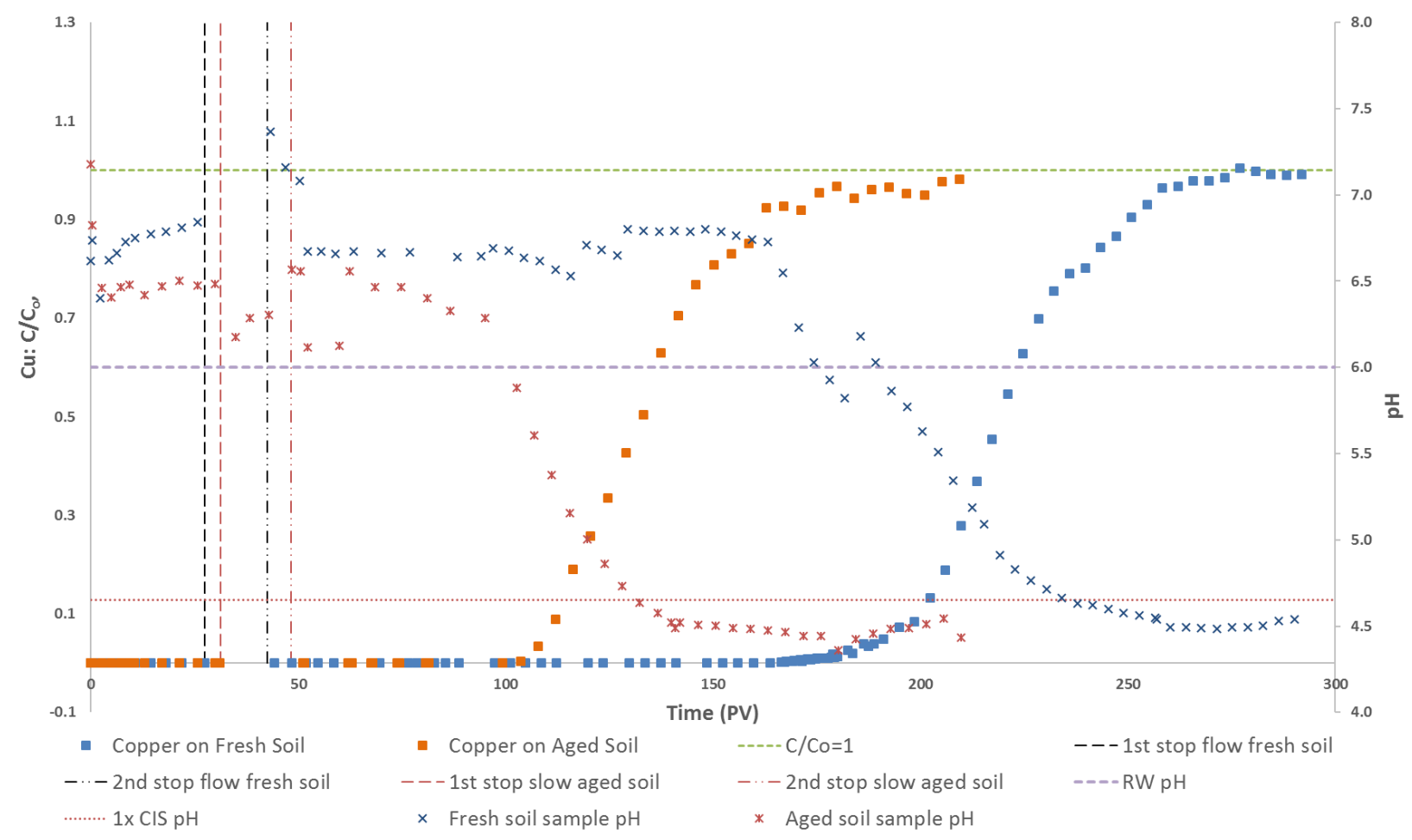

Figure 12: Comparison of copper concentration of copper solution (pH 4.9) on fresh and aged soils with sample pH indicated. 


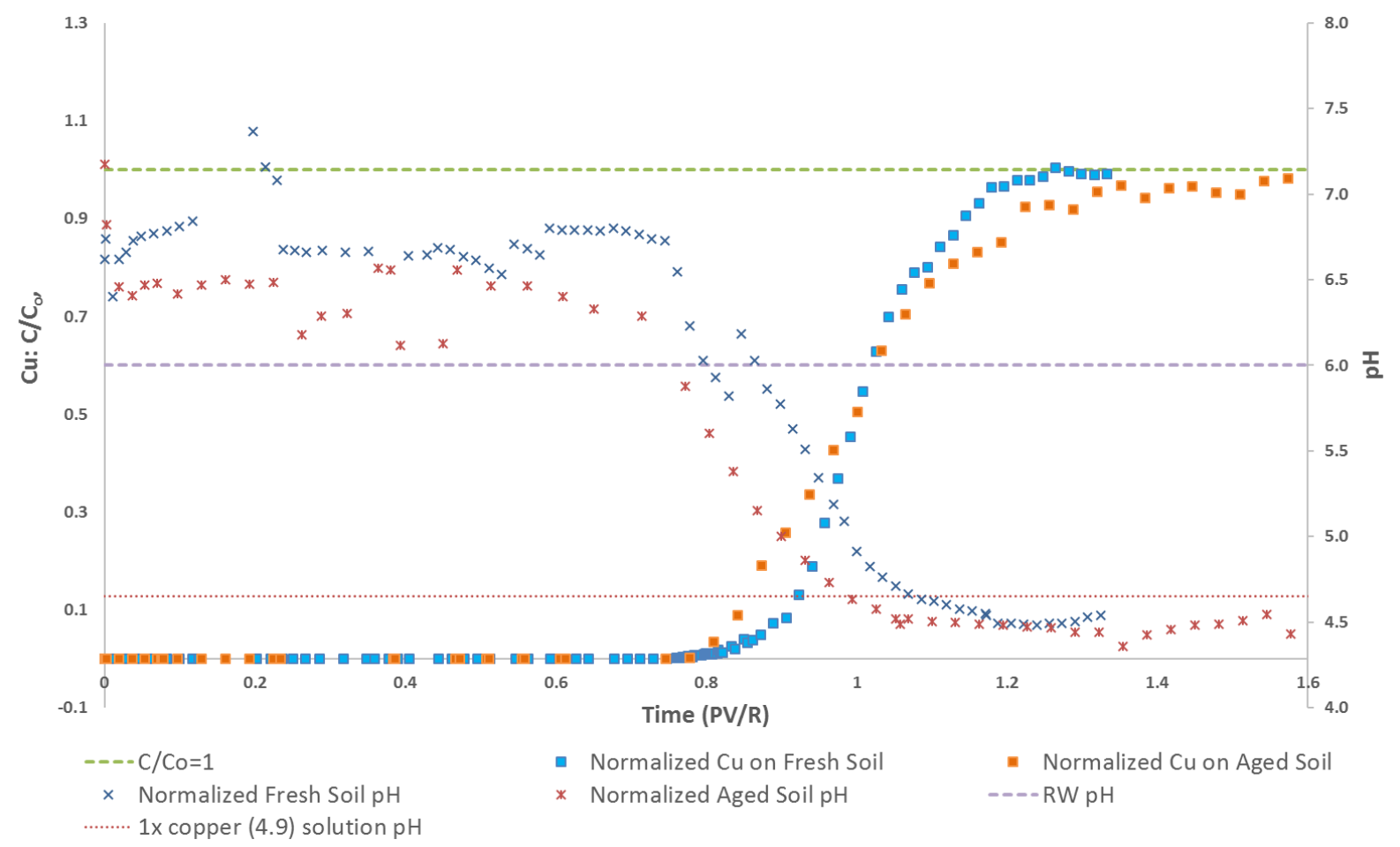

Figure 13: Normalized curves from Figure 12: to compare curve shape of copper arrival of copper solution (pH 4.9) on fresh and aged soils with sample $\mathrm{pH}$ indicated.

For all columns, the best $\mathrm{pH}$ readings were obtained from samples that were read within 30 minutes of the sample eluting from the column. Initially in Figure 10, the $\mathrm{pH}$ increased due to the buffering capacity of the natural soil then dropped to the $\mathrm{pH}$ of the injected mixed trace metals solution (pH 1.9). Copper injection solution on both the fresh and aged soils (Figures 11, 12 and 13) showed similar buffering capacity, though the buffering capacity of the fresh soil appears to be greater than that of the aged soil.

From the copper injection solution at normal environmental $\mathrm{pH}$ (6.0) (Figure 7), the aqueous copper in the solution precipitated either on or near the soil matrix when encountering the higher $\mathrm{pH}$ condition in the column as the soil buffered the influent, as seen in Figures 10-12. If the copper precipitated on the soil matrix, it may be forming organo-complexes. If it precipitated near, but not on, the soil matrix, the fresh soil may act as a cake-layer filter, preventing the movement of the copper precipitate. Either way, not much copper remained available in solution to bind to the rest of the soil matrix (e.g. Top $1 / 2$ and Top $1 / 4$ ). This data combined with the information that for the aged soil field samples; $0-30 \mathrm{~cm}$ vs $31-60 \mathrm{~cm}$ vs $61-90 \mathrm{~cm}$ depth had orders of magnitude less 
copper the deeper the samples were taken (data obtained from independent lab), suggests that the aged soil may also have the same mechanisms preventing copper mobility. The $\mathrm{pH}$ of the irrigation water used at the field site was not measured. However, the discharge from the Hyperion Treatment Plant (HTP) has been measured in the range of $\mathrm{pH} 6.6$ to 7.1 with an average $\mathrm{pH}$ of 6.8 (L.A. B.O.S., 2009).

Figures 14 shows a comparison of the arrival waves of copper on fresh soil from three copper solutions (mixed trace metal solution $\mathrm{pH} 1.9$, copper injection solution $\mathrm{pH} 2.2$, and copper injection solution $\mathrm{pH}$ 4.9). With breakthrough occurring at approximately 7, 40 and 160 pore volumes for solutions at $\mathrm{pH} 1.9,2.2$, and 4.9 , respectively; it is clear that while $\mathrm{pH}$ plays a role in the overall uptake of copper from solution, it is possible the presence of other trace metals also has an effect. This also suggests that the overall binding capacity for copper in the aged soil will be lower in the presence of other trace metals.

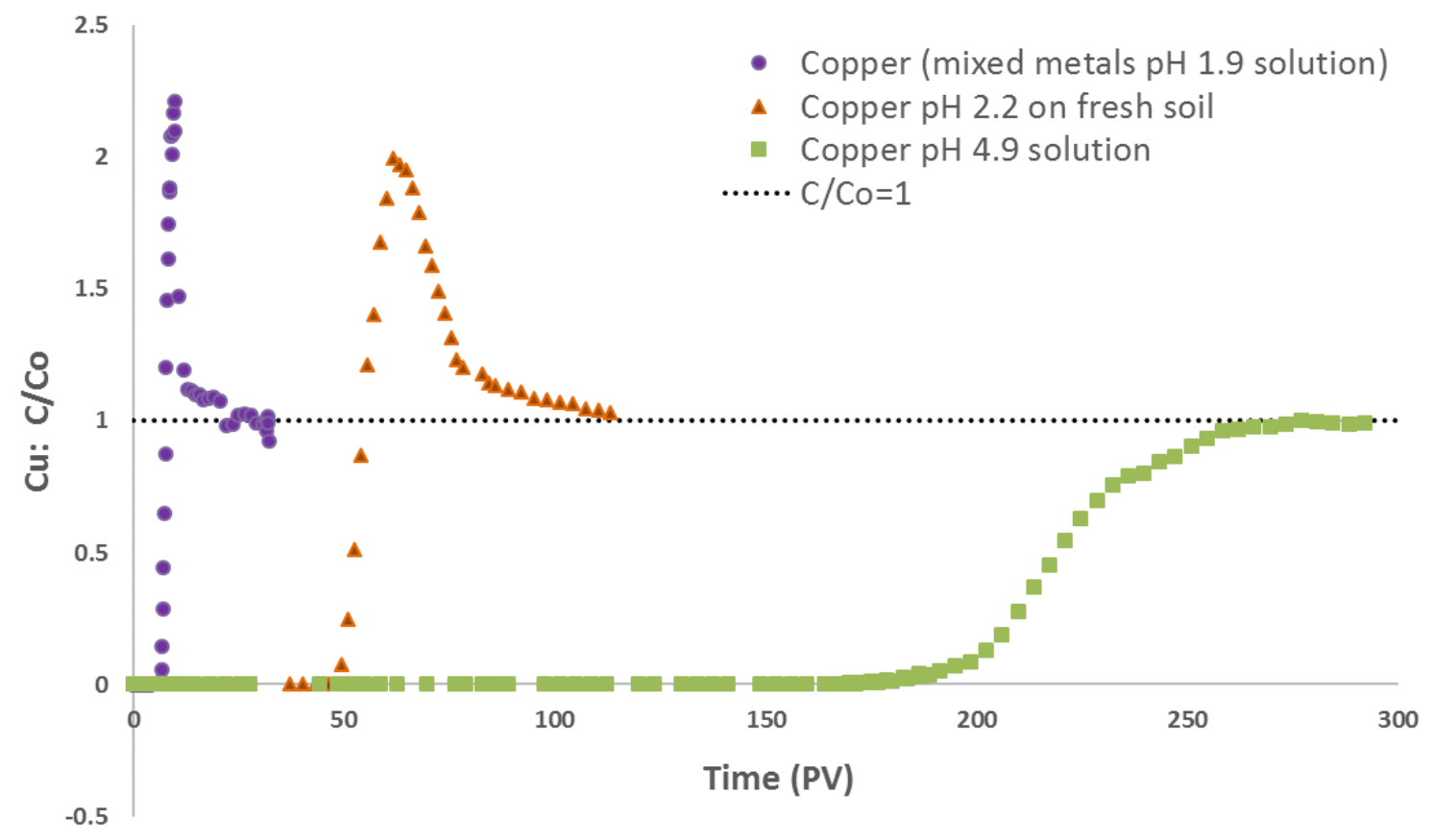

Figure 14: Comparison of copper arrival curves on fresh soil for each injection solution.

The difference in $\mathrm{pH}$ of the mixed metals solution $(\mathrm{pH} 1.9)$ and the copper $\mathrm{pH} 2.2$ solution may be significant in the arrival of copper in the fresh soil. The proton concentration in the mixed metals solution is twice that of the copper $\mathrm{pH} 2.2$ solution, 0.0126 Molar and 0.0063 Molar respectively. 
The $\mathrm{pH}$ of the samples at $\mathrm{C} / \mathrm{C}_{0}=0.5$ for these two low $\mathrm{pH}$ solutions were calculated. The $\mathrm{pH}$ in the trace metals solution was interpolated to be 3.27 at approximately 7.3 PV. Fewer samples in the copper $\mathrm{pH} 2.2$ condition were analyzed for $\mathrm{pH}$ within the 30 minute post-elution period so the $\mathrm{C} / \mathrm{C}_{0}$ $=0.5 \mathrm{pH}$ needed to be extrapolated from two nearby data points that did not include the $\mathrm{C} / \mathrm{C}_{0}=0.5$ within the range. The possible $\mathrm{pH}$ range is 5.53-5.59 at just over $52 \mathrm{PV}$. It is not clear that the difference in initial solution $\mathrm{pH}$ alone can account for the rapid $\mathrm{pH}$ decline of the column and early arrival of copper in the eluate in the fresh soil. In fact, at PV 4.5 of the mixed metals solution injection, the sample $\mathrm{pH}$ was 4.7 and coincided with the arrival of iron and no copper detected for another two PV. While at pH 4.7 in the copper pH 2.2 condition (between 57 and $58 \mathrm{PV}$ ) there was enhanced arrival of copper. To further analyze the role mixed metals may have in the early arrival of copper on fresh soil, the three curves in Figure 14 were normalized (Figure 15).

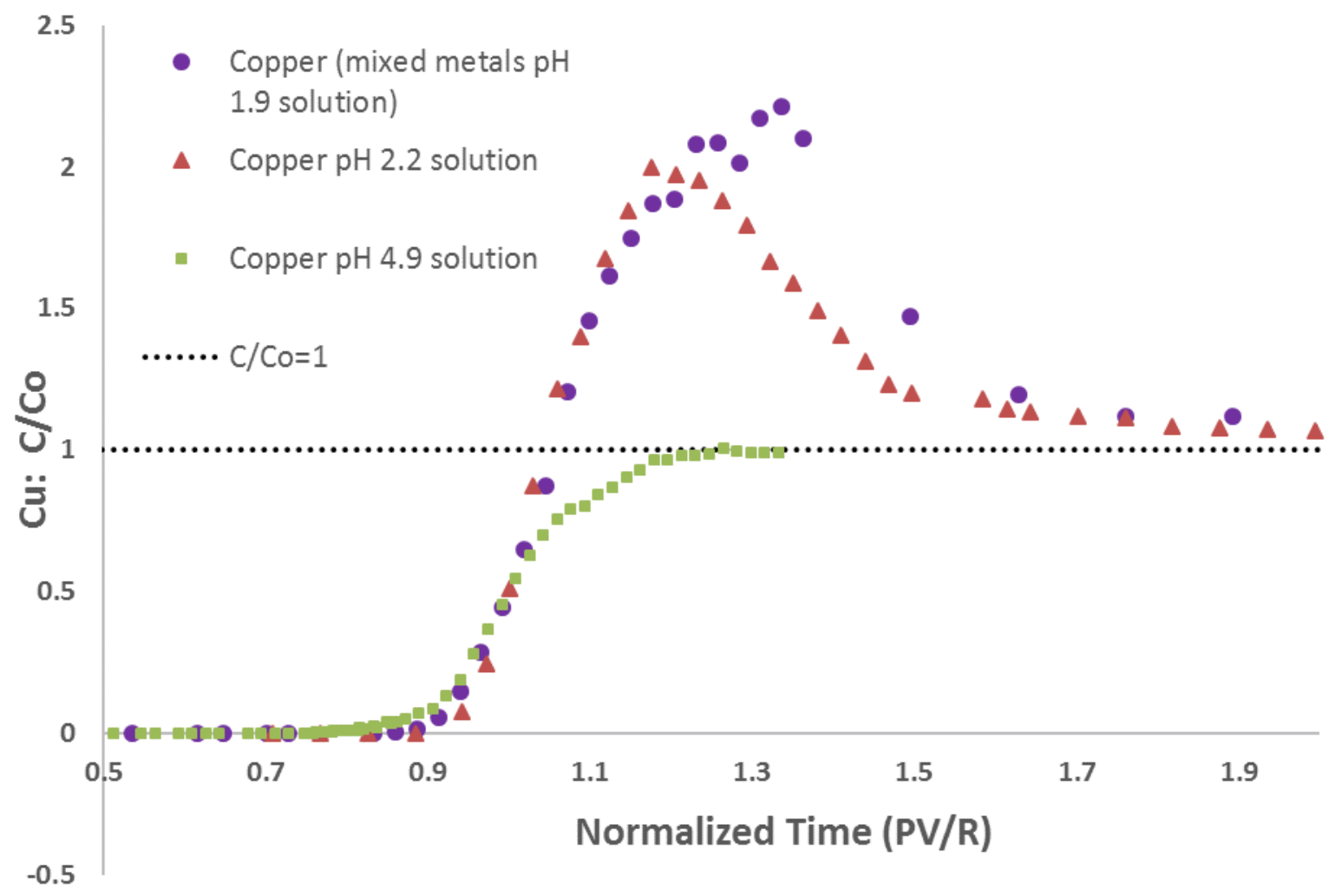

Figure 15: Normalized comparison copper curves (from Figure 14) on fresh soil for each injection solution. 
The shapes of the three curves are similar, but there are some important differences. Copper $\mathrm{pH}$ 4.9 solution shows several slopes during copper's arrival, mainly the shallow slope at the initial arrival then becoming much steeper. This may be a result of the composition of available OM binding sites. Copper will fill the sites that are easiest to bind to first (shallow slope) then fill the more complex sites (steeper slope) which may possess a rate-limited mass transfer component that is not met by the flow rate. Both low $\mathrm{pH}$ injection solutions appear to have only one slope. The copper pH 2.2 has a lower enhanced arrival peak than mixed metals as well as a more gradual return to $\mathrm{C} / \mathrm{C}_{0}=1$. These observations suggest that $\mathrm{pH}$ is not the only cause of the difference in copper transport for these two low $\mathrm{pH}$ solutions.

To understand the mechanism of the enhanced arrival under some conditions, several experiments were designed involving sectioning the soil columns after exposure to copper at varying $\mathrm{pH}$ and for different durations (Figure 16). The columns that were sectioned and prepared for acid digest include: copper solution at $\mathrm{pH} \mathrm{6;} \mathrm{copper} \mathrm{solution} \mathrm{at} \mathrm{pH} 4.9$ with final concentration of eluate allowed to reach initial concentration of influent; and two columns at pH 2.2 (one allowed to obtain $\left.\mathrm{C}_{\mathrm{f}} / \mathrm{C}_{0}=1\right)$ and the second column stopped just after copper detection in solution $\left(\mathrm{C}_{\mathrm{f}} / \mathrm{C}_{\circ}\right.$ $=0.01)$. Both $\mathrm{pH} 2.2$ columns used the same influent solution. In this second column $\left(\mathrm{C}_{\mathrm{f}} / \mathrm{C}_{0}=0.01\right.$, $\mathrm{pH} 2.2$ ), the layer with the largest copper concentration is the Top $1 / 2$. The other three layers of the two pH 2.2 columns have very similar copper concentrations, which are lower than $\mathrm{pH} 4.9$ but higher than $\mathrm{pH} 6.0$ except for the initial (bottom) $\mathrm{pH} 6.0$ layer. 


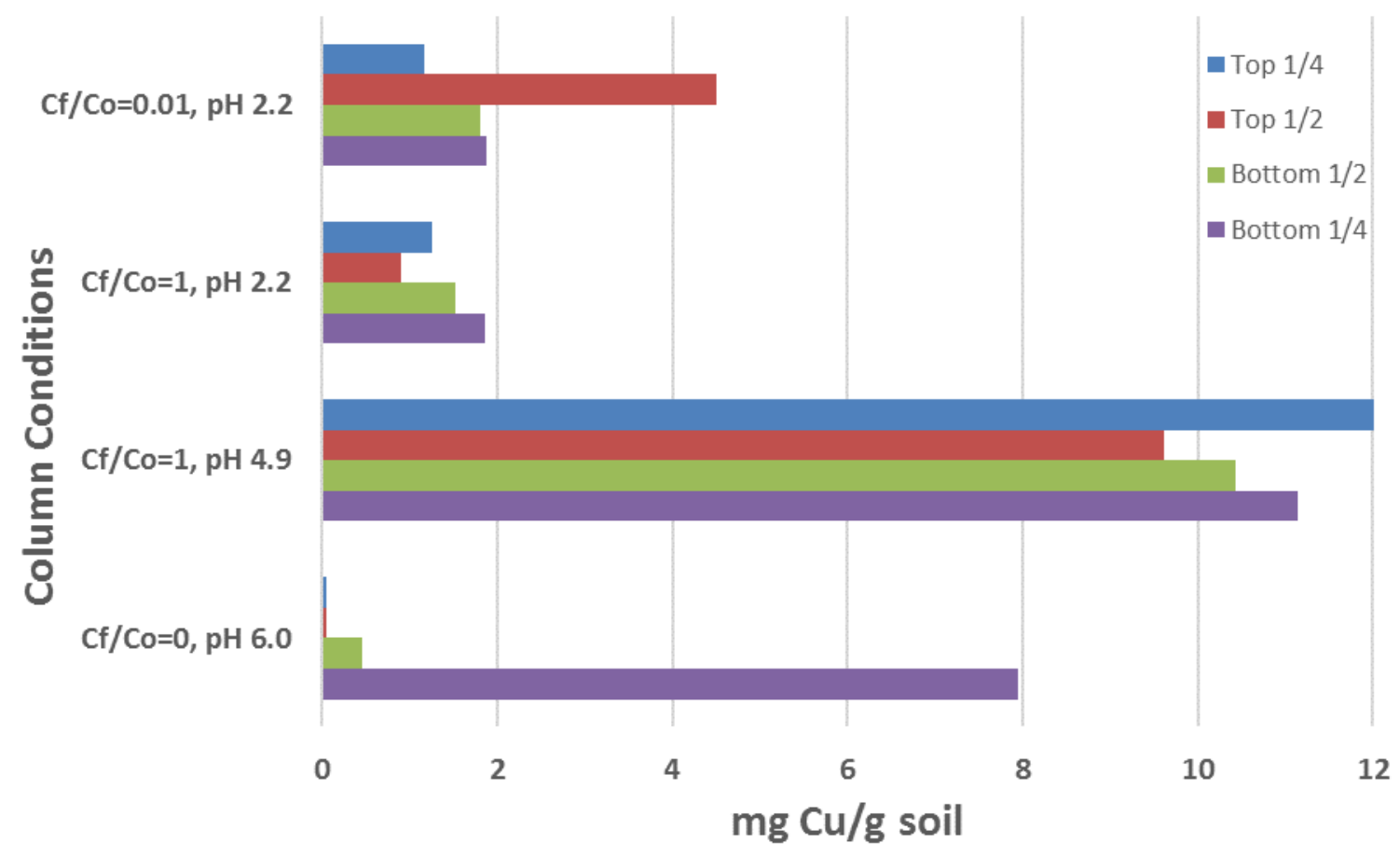

Figure 16: Copper concentrations at different levels in the fresh soil column under various conditions. $\mathbf{C f}=$ final concentration, $\mathrm{Co}=$ initial concentration

Copper injection solution at pH4.9 exhibited no enhanced arrival (Figures 12) and all column layers had high copper concentrations associated with them (Figure 16). This suggests that copper is precipitating and/or binding to the soil matrix and being retained by the media. Figure 16 also shows a large bolus of copper in the Top $1 / 2$ layer from the $\mathrm{C}_{\mathrm{t}} / \mathrm{C}_{0}=0.01$, pH2.2 condition, just as copper is starting to elute from the column (e.g. as $\mathrm{pH}$ of eluate is dropping and just before seeing the enhanced arrival of copper). This suggests that the aqueous copper in the $\mathrm{pH} 2.2$ solution initially precipitated as the influent encountered the higher initial $\mathrm{pH}$ of the column conditions, due to the soil buffering. This precipitate then dissolved and mobilized as the overall $\mathrm{pH}$ of the column dropped with continued flow of low $\mathrm{pH}$ solution. This allowed for concentrations in the eluate to be higher than the initial influent concentration. The copper bolus in the Top $1 / 2$ layer is the mobilized, dissolved copper precipitate, just prior to elution that will produce the enhanced arrival of copper. This enhanced arrival is not seen in the $\mathrm{pH} 4.9$ copper solution because once bound (e.g., organoor precipitated) at the higher initial $\mathrm{pH}$ of the column, copper may not solubilize again once the system returns to $\mathrm{pH} 4.9$. Solubilization of precipitated or organo-copper complexes may require more acidic conditions. 
This suggests that at normal environmental $\mathrm{pH}$ the copper should stay in the upper layers of the soil. If there were to be an event where $\mathrm{pH}$ were to drop, this high 'stored' copper (precipitated copper and copper bound to the soil matrix) content may become mobile. This is especially true if the buffering capacity of the soil is diminished through weathering.

A second column was run under similar conditions to Figure 10, with mixed trace metals solution $\mathrm{pH} 1.9$, but with stop flows added (Figure 17). This figure shows varying copper versus iron concentration levels just pre- and post-stop flow. The first stop flow ( 9 PV) had a duration of 13.38 hours and the second stop flow ( 32 PV) duration was for 155.67 hours. For both stop flows, there was a rebound in $\mathrm{pH}$ and a drop in copper concentration eluted from the column. These drops in copper concentration were quickly follow by enhanced arrival of copper in the eluate. After the first stop flow, iron quickly spiked to near $\mathrm{C} / \mathrm{C}_{0}=1$, quickly dropped and then slowly increased to $\mathrm{C} / \mathrm{C}_{0}=1$ again. After the second stop flow, iron concentration in the eluate dropped as the copper concentration rose then both plateaued before being eluted with metal-free RW. The drops in iron concentration in both stop flows coincided with the increase and enhanced arrival of copper. Both times, as copper concentration peaked and started to drop, iron concentration mirrored copper's behavior; reaching its lowest concentration post stop flow as copper was nearing its highest then both approached $\mathrm{C} / \mathrm{C}_{0}=1$ simultaneously. 


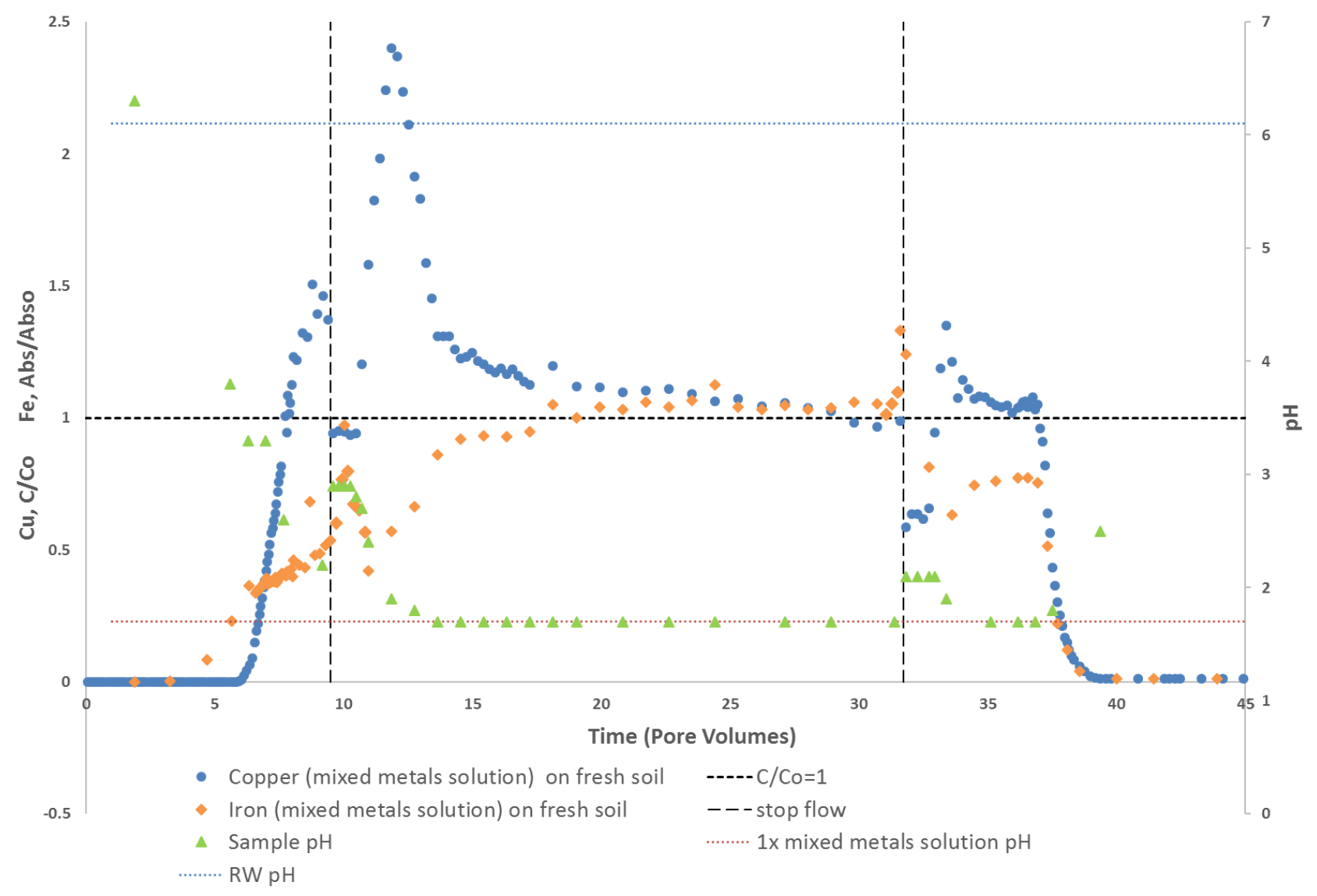

Figure 17: Mixed trace metals solution on fresh soil with several stop flow episodes.

The behavior of iron concentration decreasing in the effluent while copper exhibited enhanced arrival after stop flows (Figure 17), suggests there is rate-limited mass transfer and competition between iron and copper for soil binding sites. More tests will need to be done to evaluate this complex interaction of metals and natural porous media. 


\subsection{CONCLUSIONS}

Natural soils at a neutral $\mathrm{pH}$ may act as a cake-layer filter for copper, which can precipitate at $\mathrm{pH}$ 6 , or the copper may form organo-complexes, binding the copper to the soil matrix. This bound or filtered copper can become soluble again at a lower $\mathrm{pH}$ and become mobile. In the presence of additional trace metals, less copper binds to the soil matrix as available binding sites of the organic matter are occupied by the mix of trace metals, not just copper alone.

The behavior and interactions of copper with various soils are complex and dependent on a number of factors including $\mathrm{pH}$, presence of other trace metals and composition of the soil. As suggested in the NRC 2002 study, more funding for research on complex mixes of contaminants is needed to better understand the risk factors accompanying these mixes, possible competition for binding sites and the conditions under which they can become mobile.

Imaging the soil particles after exposure to the copper and mixed metals solution with Time-ofFlight Secondary Ion Mass Spectrometry (ToF-SIMS) and X-ray Photoelectron Spectroscopy (XPS) can determine if trace metals are sorbing to the soil particles (e.g., forming organocomplexes) or forming precipitates that are being filtered by the soil. This can inform which trace metals preferentially bind or compete for binding sites on natural soils. An analysis of treated wastewater used for irrigation to compile a pH range would enable further analysis and modeling of how trace metals and copper specifically are moving though fresh and aged soils and whether they are moving as particles, as soluble ions, on dissolved OM or a combination thereof.

Testing of lower layers in field soil column (e.g., \% OM, column transport studies, acid digests) to see if copper is able to bind and/or transport in these lower layers would inform how trace metals behave should they become mobile through the upper soil profile. This will help determine if these trace metals bind or stay mobile in lower layers. Transient flow should also be evaluated, since irrigation and rainfall are intermittent allowing for drying of the soil matrix. Additionally, a control sample obtained from the same site (e.g., either with no biosolids application or with little metals exposure) should be identified and evaluated. This will reduce or eliminate the effects of varying soil composition.

It is important to remember that prevention is less costly than clean up. Pretreatment of the large volume, low concentration of trace metals in industrial discharge either on-site or at wastewater 
treatment plants with disposal of the sediments (not allowing them to be incorporated with biosolids) would help either reduce or eliminate this source of trace metals contaminants in biosolids. While not new, bio-swales and other Low Impact Developments (LIDs) to remove trace metals from runoff from parking lots and roadways (this also should incorporate street cleaning) need to be more widely utilized. The expended media from the catchment structures also needs to be disposed and not incorporated into biosolids. The $\mathrm{pH}$ of disposal sites, such as landfills, is currently regulated and monitored. Data from new studies will also help ensure contaminants do not become mobile from these disposal sites. 


\subsection{REFERENCES}

A.C. Chang, J. W. A. P. L. L., 1984. Accumulation of Heavy Metals in Sewage Sludge-Treated Soils. Journal of Environmental Quality, pp. 87-91.

Agencies, C. -. C. A. o. S., 2017. An Evaluation of the Sustainability of Biosolids Use as Landfill Burial or Beneficial Cover Material, Sacramento, California: s.n.

Al-Saydeh, S. A., El-Naas, M. H. \& Zaidi, S. J., 2017. Copper removal for industrial wastewater: A comprehensive review. Journal of Industrial and Engineering Chemistry, Volume 56, pp. 35-44.

Benedetti, M. F. et al., 1995. Metal Ion Binding to Humic Substances: Application of the Non-Ideal Competitive Adsorption Model. Environmental Science Technology, Volume 29, pp. 446-457.

CASA, C. A. o. S. A., 2017. An Evaluation of the Sustainability of Biosolids Use as Landfill Burial or Beneficial Cover Material, Sacramento, California: s.n.

Chang, A., Warneke, J., Page, A. \& Lund, L., 1984. Accumulation of Heavy Metals in Sewage Sludge-Treated Soils.

Journal of Environmental Quality, pp. 87-91.

City of Los Angeles, Department of Public Works \& Bureau of Sanitation, March 2014. Biosolids Fact Sheet Series (no subtitle, : Handling, : Monitoring, : Management, : Production), Los Angeles, CA: Public Affairs Office.

Clary, J., Leisenring, M. \& Hobson, P., 2011. Pollutant Category Summary; Metals, Portland, OR: International Stormwater Best Management Practices (BMP) Database.

Coruh, S., Ergun, O. N. \& Cheng, T.-W., 2006. Treatment of copper industry waste and production of sintered glassceramic. Waste Management \& Research, Volume 24, pp. 234-241.

Dafeta, T., 2015. City of Los Angeles Hyperion WWTP - 2014 Biosolids Annual Report, Los Angeles, CA: Bureau of Sanitation, Board of Public Works.

Division, E. M., 2009. Santa Monica Bay Biennial Assessment Report 2007-2008, Los Angeles, CA: City of Los

Angeles, Department of Public Works; Bureau of Sanitation.

Dowdy, R. et al., 1991. Trace Metal Movement in an Aeric Ocharqualf following 14 Years of Annual Sludge

Applications. Journal of Environmental Quality, pp. 119-123.

EPA, June 1994. Biosolids Recycling: Beneficial Technology For A Better Environment, Washington, DC: Office Of

WaterResource Center.

EPA, September 1994. A Plain English Guide to the EPA Part 503 Biosolids Rule, Washington, DC: Office of

Wastewater Managment.

Forster, C. F., 2003. Wastewater Treatment and Technology. s.l.:Thomas Telford Ltd.

Garrido-Rodriguez, B. et al., 2014. Competitive adsorption and transport of $\mathrm{Cd}, \mathrm{Cu}, \mathrm{Ni}$ and $\mathrm{Zn}$ in a mine soil amended with mussel shell. Chemosphere, pp. 379-385.

Hoogsteen, M. et al., 2015. Estimating soil organic carbon through loss on ignition: effects of ignition conditions and structural water loss. European Journal of soil Science, pp. 320-328.

Hu, L. et al., 2010. Transport and interaction of arsenic, chromium, and copper associated with CCA-treated wood in columns of sand and sand amended with peat. Chemosphere, pp. 989-995.

Hussain, A., Maitra, J. \& Khan, K. A., 2017. Development of biochar and chitosan blend for heavy metals uptake from synthetic and industrial wastewater. Applied Water Science, Volume 7, pp. 4525-4537.

Junge, C. E., 1958. The distribution of ammonia and nitrate in rain water of the United States. Transactions, American Geophysical Union, pp. 241-248.

Junge, C. E. \& Werby, R., 1958. The concentration of chloride, sodium, potassium, calcium, and sulfate in rain water over the United States. Journal of Meteorology, pp. 417-425.

Kumar, M., Furumai, H., Kurisu, F. \& Kasuga, I., 2013. Potential mobility of heavy metals through coupled application of sequential extraction and isotopic exchange: Comparison of leaching tests applied to soil and woakaway sediment. Chemosphere, pp. 796-804.

L.A. B.O.S, E. M. D., 2009. Santa Monica Bay Biennial Assessment Report 2007-2008, Los Angeles, CA: City of Los Angeles, Department of Public Works; Bureau of Sanitation.

Landrigan, P. J., Ruller, R. \& Acosta, N. J., 2017. The Lancet Commission on pollution and health. The Lancet, 0(0), p. http://dx.doi.org/10.1016/.

Langmuir, D., Chrostowski, P., Vigneault, B. \& Chaney, R., 2004. Issue Paper on the Environmental Chemistry of Metals, Lexington, MA: ERG.

Lewis, J. \& Sjostrom, J., 2010. Optimizing the experimental design of soil columns in saturated and unsaturated transport experiments. Journal of Contaminant Hydrology, pp. 1-13. 
Machno, P. S. \& Leonard, P., 2017. Biosolids remediate metal-contaminated soils. [Online]

Available at: http://www.pollutionissues.com/A-Bo/Biosolids.html

[Accessed 13 December 2017].

McIntyre, J. K., Baldwin, D. H., Beauchamp, D. A. \& Scholtz, N. L., 2012. Low-level copper exposures increase visibility and vulnerablilty of juvenile coho salmon to cutthroat trout predators. Ecological Applications, 22(5), pp. 1260-1471.

McKenzie, E. R., Money, J. E., Green, P. G. \& Young, T. M., 2009. Metals associated with stormwater-relevant brake and tire samples. Science Total Environment, 407(22), pp. 5855-5860.

Moller, R. M., 2007. A Brief on Biosolids: Options for Biosolids Management, Scramento, CA: California State Library, California Research Bureau.

Muenning, P., 2016. The Social Costs of Lead Poisonings. Health Affairs, 35(8), p. 1545.

National Research Council, 2002. Biosolids Applied to Land: Advancing Standards and Practices. Washington, DC:

The National Academies Press.

Neirop, K. G., Jansen, B., Vrugt, J. A. \& Verstraten, J. M., 2002. Copper complexation by dissoved organic matter and uncertainty assessment of their stability constants. Chemosphere, Volume 49, pp. 1191-1200.

Office of the Science Advisor, Risk Assessment Forum, 2007. Framework for Metals Risk Assessment, Washington, DC: EPA.

Office of Water, 2009. Targeted Nation Sewage Sludge Survey, Washington, DC: EPA.

Office of Water, 2015. Report on the Elemental Analyses of Samples from the Targeted National Sewage Sludge

Survey, Washington, DC: EPA.

Paradelo, M. L. A., Arias-Estevez, M., Garrido-Rodriguez, B. \& Lopez-Periago, J. E., 2011. Influence of soluble copper on the electrokinetic properties and transport of copper oxychloride-based fungicide particles. Journal of Contaminant Hydrology, pp. 37-44.

Pena-Icart, M. et al., 2011. Comparative study of digestion methods EPA 3050B (HNO3-H2O2-HCl) and ISO 11466.3 (aqua regia) for $\mathrm{Cu}, \mathrm{Ni}$ and $\mathrm{Pb}$ contamination assessment in marine sediments. Marine Environmental Research, pp. 6066.

R.H. Dowdy, J. L. T. H. R. G. D. S., 1991. Trace Metal Movement in an Aeric Ocharqualf following 14 Years of Annual Sludge Applications. Journal of Environmental Quality, pp. 119-123.

Sanburn, J., 2016. Flint Water Crisis May Cost the City \$400 Million in Long-Term Social Costs. [Online]

Available at: http://time.com/4441471/flint-water-lead-poisoning-costs/

[Accessed 13 December 2017].

Schroder, J. et al., 2008. The Effect of Long-Term Annual Application of Biosolids on Soil Properties, Phosphorus, and Metals. Soil Science Society of America, 72(1), pp. 73-82.

Science, P., 2016. Popular Science. [Online]

Available at: https://www.popsci.com/whats-wrong-with-flint-river

[Accessed 13 December 2017].

Tipping, E., 2005. Modelling A1 competition for heavy metal binding by dissolved organic matter in soil and surface waters of acid and neutral pH. Geoderma, Volume 127, pp. 293-304.

Tipping, E., Rey-Castro, C., Bryan, S. E. \& Hamilton-Taylor, J., 2002. Al(III) and Fe(III) binding by humic substances in freshwaters, and implications for trace metal speciation. Geochimica et Cosmochimica Acta, 66(18), pp. 3211-3224.

Walker, J., Knight, L. \& Stein, L., September 1994. A Plain English Guide to the EPA Part 503 Biosolids Rule, Washington, DC: Office of Wastewater Managment.

Walker, J. \& Stein, L., 1995. A Guide to the Biosolids Risk Assessments for the EPA Part 503 Rule, Washington DC: US Environmental Protection Agency.

Works, S. \& Facilities, S. C. A. o. P. O. T., 2015. 2014 SCAP Biosolids Trends Survey, Encinitas, California: s.n. Wu, C. et al., 2010. Uptake of Pharmaceutical and Personal Care Products by Soybean Plants from Soils Applied with Biosolids and Irrigated with Contaminated Water. Environmental Science Technology, Volume 44, pp. 6157-6161. Xing, Y., Chen, X., Chen, X. \& Zhuang, J., 2016. Colloid-Mediated Transport of Pharmaceutical and Personal Care Products through Porous Media. Nature Scientific Reports, Volume 6, p. 34507. 